Meine van Noordwijk, Edmundo Barrios, Keith Shepherd, Jules Bayala and Ingrid Öborn multifunctional landscape: Soil science at the World Agroforestry Centre

The rooted pedon in a dynamic
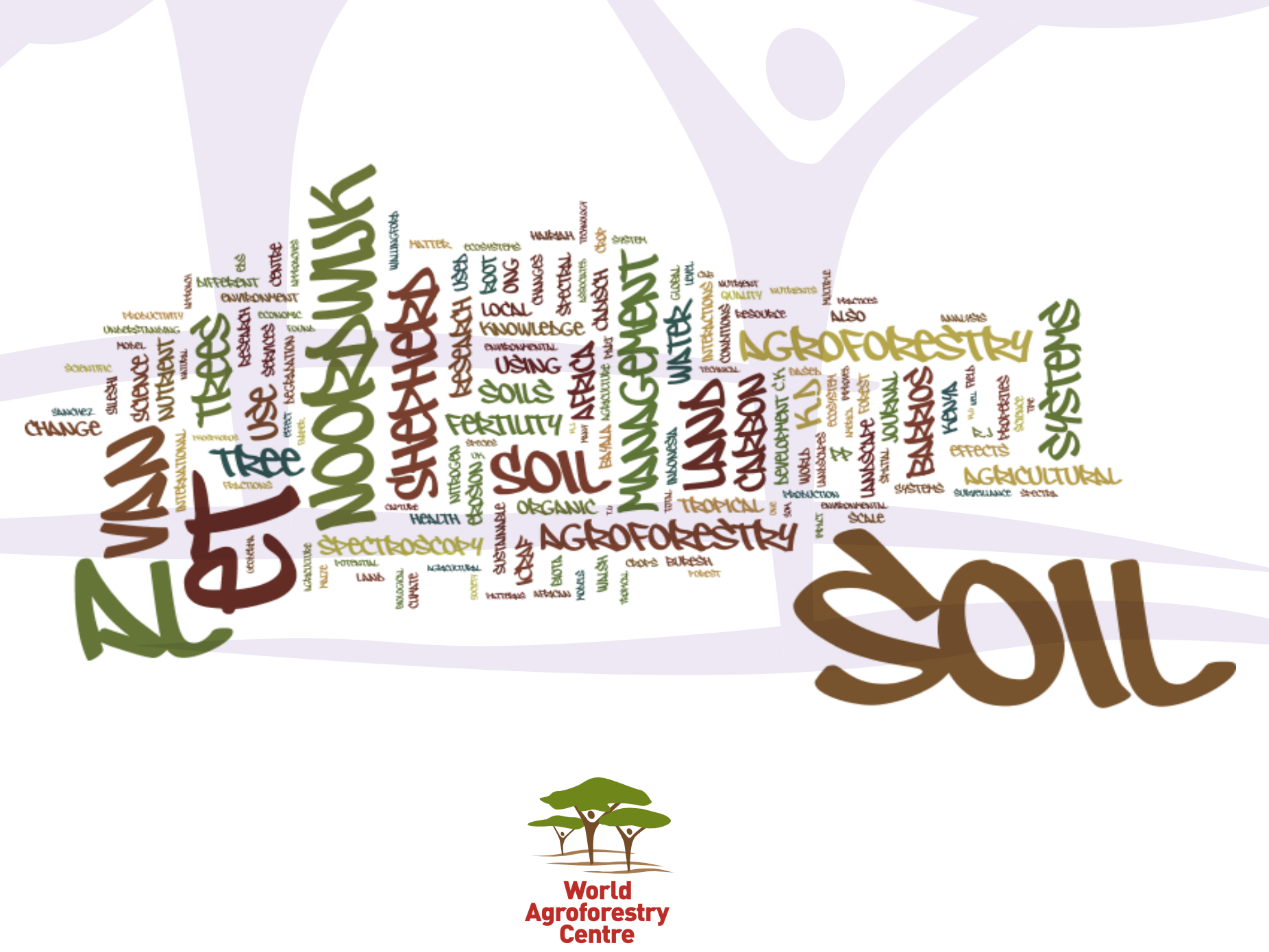



\section{The rooted pedon in a dynamic multifunctional landscape: Soil science at the World Agroforestry Centre}

Meine van Noordwijk, Edmundo Barrios, Keith Shepherd, Jules Bayala and Ingrid Öborn 


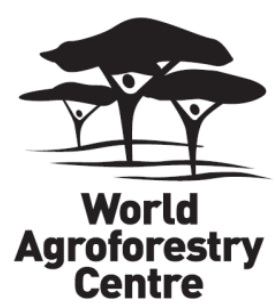

\section{Correct citation:}

Van Noordwijk M, Barrios E, Shepherd K, Bayala J, Öborn I. 2015. The rooted pedon in a dynamic multifunctional landscape: Soil science at the World Agroforestry Centre. Working Paper 200. Nairobi, Kenya: World Agroforestry Centre (ICRAF). DOI: 10.5716/WP15023.PDF

Titles in the Working Paper Series share interim results on agroforestry research and practices to stimulate feedback from the scientific community. Other publication series from the World Agroforestry Centre include agroforestry perspectives, technical manuals and occasional papers.

Published by the World Agroforestry Centre

United Nations Avenue

PO Box 30677, GPO 00100

Nairobi, Kenya

Tel: +254(0)20 7224000, via USA +1 6508336645

Fax: +254(0)20 7224001, via USA +1 6508336646

Email: icraf@cgiar.org

Internet: www.worldagroforestry.org

(C) World Agroforestry Centre 2015

Working Paper nr 200

\section{Disclaimer and copyright}

The views expressed in this publication are those of the author(s) and not necessarily those of the World Agroforestry Centre. Articles appearing in this publication may be quoted or reproduced without charge, provided the source is acknowledged. All images remain the sole property of their source and may not be used for any purpose without written permission of the source. 


\section{About the authors}

Meine van Noordwijk is the Chief Science Advisor at the World Agroforestry Centre (ICRAF) based in Bogor, Indonesia. He leads the Landscape Multifunctionality and Environmental Services program of the CGIAR Research Program on Forests, Trees and Agroforestry, and is parttime Professor in Agroforestry at Wageningen University (the Netherlands). His research started in biology and soil science with details at a scale of a rooted pedon as basis for understanding tree-soil-crop interactions at plot and tradeoffs at landscape scales. Analysis of watershed functions and landscape multifunctionality in tropical forest margins brought him to his current focus on landscapes as dynamic socio-ecological systems, where key feedback loops need to be strengthened.

Edmundo Barrios is a Senior Scientist in Land and Soil Management at the World Agroforestry Centre (ICRAF) based in Nairobi, Kenya. His work focuses on understanding the ecological basis of sustainable land management in agricultural landscapes and the contribution of local knowledge systems to the capacity to adapt to disturbance and to shape change in natural resource management. He leads the Living Soils Laboratory which studies the role of agroforestry trees in restoring and sustaining the biological activity that underpins soil-mediated ecosystem services. Edmundo also leads the South-South participatory research efforts to blend local and scientific knowledge on indicators of soil health.

Keith Shepherd leads the World Agroforestry Centre (ICRAF) Science Domain on Land Health Decisions. His research on land health surveillance and response focuses on monitoring and assessing land/soil health and risks, and targeting interventions for land improvement. He leads a Soil-Plant Spectral Diagnostics Laboratory, which deploys new light-based analytic techniques for low cost high-throughput analysis. The lab supports the Africa Soil Information Service (AfSIS), landscape carbon measurement and sustainable land management projects. Keith also leads a research thrust on decision analysis and applied information economics aimed at improving development decisions under uncertainty and prioritising high value research.

Jules Bayala is a Senior Scientist with the World Agroforestry Centre. He holds a $\mathrm{PhD}$ in Ecophysiology and Agroforestry from the University of Wales, Bangor, UK. He is currently working on establishing key directions for the agroforestry research and development program in the Sahel. His research focus is on the soil-plant-atmosphere continuum in West and Central Africa and agroforestry species physiology in the face of climate change.

Ingrid Öborn is Senior Research Fellow at the World Agroforestry Centre (ICRAF) in Nairobi, Kenya, and Professor of Agricultural Cropping Systems at the Swedish University of Agricultural Sciences (SLU). She holds a PhD in Soil Science. Research interests include (i) multi-functionality of agro-ecosystems including agroforestry, integrating improved productivity and natural resource management with food and nutrition security, and their synergies and trade-offs, (ii) biogeochemistry - nutrient and trace element flows and dynamics in agricultural systems and the food chain - including soil mineral weathering, and (iii) foresight and future studies and methodologies related to food security, agricultural systems and natural resource management. 


\section{Abstract}

Soil research has been a prominent part of the agroforestry research agenda from the start of the current World Agroforestry Centre as ICRAF in 1978 with a focus on new answers to land degradation problems. Early hopes that, in order to be widely adopted, agroforestry primarily lacked policy support and effective extension rather than research, proved to be too simple. While policy attention was drawn to the need for soil replenishment in Africa and for alternatives to slash-and-burn throughout the humid tropics, the specific ways to achieve these goals in the local context were under investigation. A research agenda was framed that saw trees on farms and in agricultural landscapes as ways to conserve and improve soil carbon (C) stocks, add nitrogen (N) by use of $\mathrm{N}_{2}$-fixing trees, mobilize poorly available phosphorous $(\mathrm{P})$ sources and capture deep soil nutrient stocks and mobile nutrients on the way out by leaching. Simultaneously the trees should be a source of valuable products (such as firewood, timber, fodder, fruits, medicinal bark and roots), a regulator of (micro)climate and watershed functions, and a provider of supportive functions for crops and animals. In doing so the experience with bottom-up approaches showed that local ecological knowledge of soils included classifications and functional insights complementary to what formal science had as yet explored. A phase of research on hypotheses at process level, analyzing the various tree-soil-crop interactions one by one, was followed by the construction of synthetic simulation models. Meanwhile, the early use of plot level experimentation, inherited from agronomic traditions, proved to be a challenge as lateral tree roots were difficult to control unless plot sizes were large and replicated trials huge. Beyond plotlevel experiments, research shifted from characterizing to managing lateral resource flows and filter functions, reinterpreting the earlier erosion control emphasis at hill-slope and landscape scales. Dynamics of soil water led to quantification of soil structure and its dependence on root-based carbon inputs, old tree root channels and earthworms. Further soil biological work was focused on mycorrhiza, rhizobia, nematodes and other soil biota. The more fundamental understanding of soil biology, led to early work on soil carbon dynamics and greenhouse gas emissions from tropical land use, especially in humid tropical forest margins. Reducing and avoiding below- and aboveground emissions were combined in the search for alternatives to slash and burn. Understanding the underlying principles required for sustainable and profitable land use, with or without trees, contributed to a general trend where promises of packaged technology evolved into supporting farmer knowledge and decisions. Agroforestry practices aimed at soil fertility improvement were extensively tested on farms, which led to a better understanding of the risks and benefits under different conditions. A focus on the diverse realities on farm meant that laboratory methods for soil characterization had to be scaled up and simplified. The use of soil spectral properties proved to be efficient in dealing with the spatial diversity of soils in both landscape and farm level applications. However, at the end of the day, our funders and investors want to see and be assured of pathways to development impact, and demonstrating that through changes in soil quality over the long-term and over large extents requires wider application of these methods. The concepts of soil function in multifunctional landscapes, the interdisciplinary integration of tools and approaches, and the direct linkage of growing knowledge and increased action will continue to evolve, but can be rooted in a rich tradition and are on solid ground.

Keywords: agroforestry; carbon; ecosystem services; spectroscopy; soil fertility; soil health; treesoil-crop models 


\section{Contents}

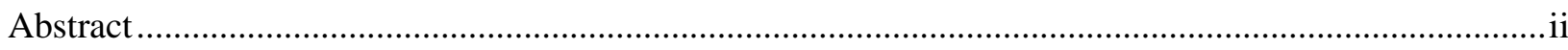

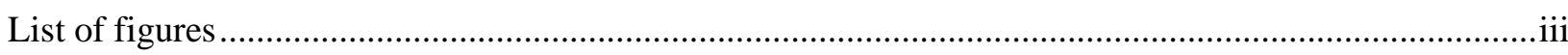

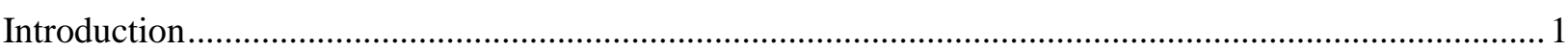

1. Soil depletion, land degradation, global climate change and loss of biodiversity ...............................2

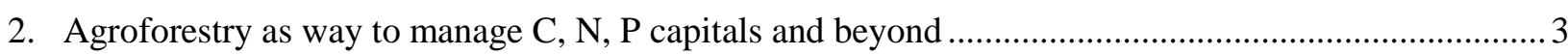

3. From process hypotheses and plot-level experiments to synthetic tree-soil-crop interaction models

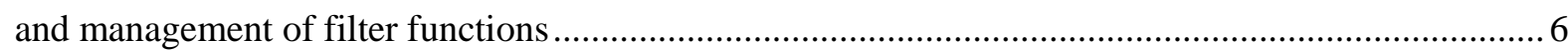

4. Trees and other soil biota: Old tree root channels, earthworms, mycorrhiza, rhizobia and nematodes 8

5. Soil carbon dynamics and greenhouse gas emissions from agroforestry systems .............................. 9

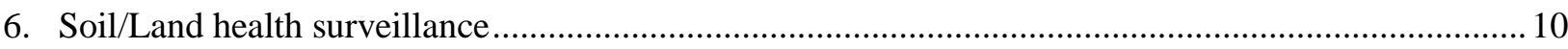

7. The challenge of demonstrating development impact through soil changes ..................................... 14

Conclusion: Soil as fundamental to a big issues agenda with attention to local knowledge ...................... 16

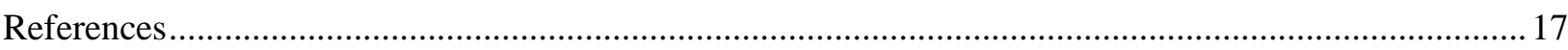

\section{List of figures}

Figure 1. Citations to ICRAF publications classified by topic and year of publication (total / \#of papers with more than 100 citations); based on Scholar.Google (May 2013); AF = agroforestry.....

Figure 2. Portable mid-infrared spectrometer being used for rapid characterization of soil samples.

Figure 3. Key concepts of research in development, that require continued diagnostics as part of monitoring and evaluation and sentinel approaches, explicit theories of change that address both variation in circumstances encountered in 'scaling out' and changes in dynamic properties as a response of 'scaling up', and that may lead to change of theory.

Figure 4. Illustration of the way land use (LU) effects on soil properties, together with the preferential positioning of land uses in specific parts of a landscape, influence survey results, with the possibility of apparent effects having opposite signs to real ones (Hoang et al., 2013). 



\section{Introduction}

The World Agroforestry Centre (ICRAF) has as its mandate all agricultural land use that involves trees, beyond what is considered to be forest. The latter distinction is rather fluid, both temporarily and institutionally, as the example of long-rotation shifting cultivation may show. Agroforestry itself ranges from croplands with a few trees added, to systems where tree crops (considered to be agricultural, such as coffee, cacao or rubber) provide a perennial vegetation layer, augmented with upper canopy layer trees utilized to modify microclimate, and yield economically valuable products. The consequences for soil conditions and functions vary along this range.

Agroforestry research has from its start operated on the active and often contested interface of the need to increase agricultural production, overall and per unit area, and the need to find more sustainable ways of managing natural resources. Agroforestry is typically associated with "integrated", rather than "segregated" solutions to meet the dual imperative, with specific attention to the understanding and management of tradeoffs at the scales of farmers, the landscape, (sub) national governments and global policy arena. Soils have a key function to both issues of land productivity and environmental effects, and soil research of one type or another has been part of nearly all research activities of ICRAF from its start.

Classifying the research output of ICRAF on the basis of citations to publications grouped by topic (Fig. 1) shows six identifiable waves. Virtually all literature on agroforestry systems and improvement or "tree-soil-crop interactions" that had been cited by 2013 had been published before 2000; by contrast, publications on agroforestry and environmental services and climate change mitigation and adaptation started in the mid 1990's and flourished after 2000. Intermediate time patterns (steady progression in time) are found for agroforestry systems in social, policy and economic context, and for tree domestication.

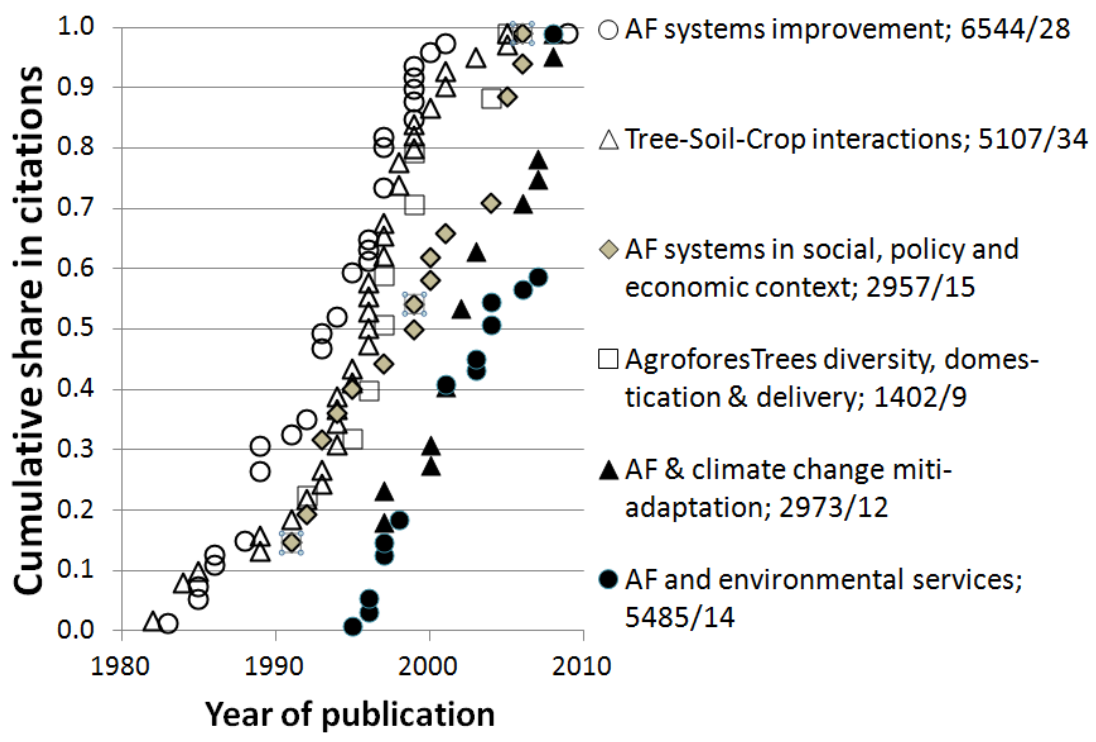

Figure 1. Citations to ICRAF publications classified by topic and year of publication (total / \#of papers with more than 100 citations); based on Scholar.Google (May 2013); AF = agroforestry

We will here review progress in agroforestry soil science in the past two decades under seven headings and provide key references for each that point to more detailed reviews and syntheses. 


\section{Soil depletion, land degradation, global climate change and loss of biodiversity}

One of the first documents produced when ICRAF was being formed described the issues of land degradation in the tropics and the urgency of finding solutions for intensification that combine technical, ecological, social and economic aspects. This topic remained important in the first ten years of ICRAF (Sanchez, 1987) and forms a red thread through thirty-five years of institutional history. Partial successes have not yet combined to the breakthroughs needed at global scale, as the issue interacts with international terms of trade, value chains for inputs and outputs in the local, national and international economy, and the dynamic rural-urban interface and its consequences for management of food prices. Arguments for public investment in soil fertility replenishment in Africa received attention (Sanchez et al., 1997), but they were not backed up by economic policy analysis, while the technical aspects of supporting phosphorus levels so that tree and grain legumes through biological nitrogen fixation could do the job of adding nitrogen to the soil were not convincing at farmer level (Soule and Shepherd, 2007; Shepherd et al., 1996a). Some success was made with fertilizer trees in fallow rotations, but national subsidies for $\mathrm{N}$-fertilizer to support grain crops won the day when food shortages became urgent again in southern Africa. Saving Africa's soils still requires a combination of policy with science and technology for improved soil management that is not yet on the shelf in Africa. The call for new initiatives to save Africa's soils remains urgent (Swift and Shepherd, 2007).

The 1992 Rio Conference where the primary global environmental conventions were shaped marked the start of a new interest in how local and (inter)national actors interacted in the process of tropical forest conversion and how changes in land use practice could be part of a package that obtained equal local benefits but substantially reduced global impacts on climate and biodiversity (Sanchez, 1995). The Alternatives to Slash and Burn (ASB) program was initiated to identify and support sustainable land use intensification in tropical forest margins, alongside protection of remaining forests. While declining soil fertility under reduced fallow length is one of the classical storylines that can be quantified in simple models (van Noordwijk, 2002), the focus of ASB was not on traditional shifting cultivation for subsistence livelihoods (van Noordwijk et al., 2008), but on its modern market-related versions. Almost from the start, the researchers recognized that slash-and-burn as a method of land clearing is used by large-scale operators as a cheap way of establishing plantations, as starting point for low-intensity grazing and as part of traditional shifting cultivation and crop-fallow rotations. The research program described patterns of land use in their social, economic and environmental context, and then focused on a comparison of consequences of various land use alternatives for an array of criteria. Soil-related constraints were found to be part of a much broader set of ecological, economic and social determinants of land use patterns (van Noordwijk et al., 1998a; 1998b). This led to analysis of tradeoffs and interest in the way drivers of business-as-usual change can be leveraged to nudge systems into a more desirable direction (Murdiyarso et al., 2002).

An important part of the ASB research agenda along the forest transition curve was the rehabilitation of abandoned land, as alternative to further deforestation. There was major confusion on whether such land areas were 'degraded' or abandoned for other reasons, for example related to tenure issues and continued forest institutional regimes that prohibited other land use (Minang et al., 2014). The extent and dynamics of Imperata grasslands in Southeast Asia were reviewed (Garrity et al., 1997), with specific attention to soil conditions. The latter were found to not be a real constraint to subsequent intensification (Santoso et al., 1997; van Noordwijk et al., 1996). 
Agricultural systems can greatly benefit from integrative approaches that combine formal and informal knowledge to address current sustainability problems associated with global change (Joshi et al., 2004a,b). There is increasing recognition of the potential value of knowledge held by land managers who have been closely interacting with their environment for a long time to contribute important insights about the sustainable management of natural resources (Barrios and Trejo, 2003). Increased concern about soil management as a key determinant of sustainability in agricultural landscapes has driven the demand for early warning indicators to monitor changes in soil health, and their impact in the provision of ecosystem services, as affected by land use change and agricultural intensification (Barrios et al., 2006; Sileshi et al., 2007). A participatory methodology has been published recently, following several years of South-South collaboration, to guide the mobilization and integration of local and scientific knowledge on indicators of soil quality and soil fertility management (Barrios et al., 2012a). It was designed to facilitate bottom up approaches that integrate local knowledge into the soil management decision making processes and strengthen the relevance, credibility and legitimacy dimensions required for the adoption of best management practices. This methodological guide describes how to apply participatory tools in identifying, classifying and prioritizing local indicators of soil health knowledge so that they can complement technical indicators, and later build farmer community consensus about how to best address soil health constraints following agroecological management principles and integrated soil fertility management options. The development of a "hybrid" knowledge base, combining local and scientific knowledge, reflects an effort to understand the complexity of the land management decision making to promote and protect multifunctional land uses (Sinclair and Joshi, 2000; Sileshi et al., 2009; Pauli et al., 2012). This is part of a continuing effort to develop land quality monitoring systems that strengthen local environmental and agricultural institutions and communities with tools that support local decision-making in natural resource management and promote sustainable land use in agricultural landscapes (Tittonell et al., 2010).

\section{Agroforestry as way to manage $C, N, P$ capitals and beyond}

In its first decade ICRAF science dealt with an inventory of the diversity of agroforestry systems of the world and their primary reasons for existence. Soil and land health management, interpreted as a combination of erosion control and maintenance of soil fertility (Young, 1997), was identified as one of the strongest rationales for combining trees, crops and livestock on sloping lands. Soil fertility improvement and better nutrient use efficiency when introducing and managing trees (serving as nutrient pumps and safety nets) in agroecosystems were the focus of research aiming at optimizing agroforestry systems (van Noordwijk and Garrity, 1995). From the crop's perspective, however, most trees in most circumstances have a direct negative effect based on competitive resource capture, and the longer term benefits of inclusion of trees will only weigh up to the negatives in well-defined circumstances (Cannell et al., 1996; Sanchez, 1995). Those circumstances potentially include, beyond sloping lands, the seriously nutrient-depleted landscapes of Africa on geologically old soils (Buresh et al., 1996, 1998; Shepherd et al., 1995).

In the 1980's major hope became vested in alley cropping or hedgerow intercropping. Inspired by farmer-developed technology on sloping lands in Flores (Indonesia), it was popularized in Africa by an Indonesian soil scientist working at IITA (Nigeria). There are many versions of the history of the hope-hype-crash dynamics of public expectations of what this technology can deliver, and how 
lessons could be learned from this experience (Coe et al., 2014). It was to be largely repeated, however, on the improved fallow and fertilizer tree story that replaced it as 'silver bullet' solution. While not ultimately leading to widespread success, the research done on hedgerow intercropping and improved fallows helped identifying underlying principles on the technical, social and economic side (Shepherd et al., 1997; Swinkels et al., 1997; Shepherd and Soule, 1998; Ndufa et al., 1999; Sjögren et al., 2010). The search for locally appropriate agroforestry solutions continued.

Many studies have shown that soil organic matter (SOM) content of soil under trees is higher than in soils outside tree influence (Bayala et al., 2007). The attribution of this pattern to aboveground litter fall and belowground root turnover depends on local context (van Noordwijk et al., 2004). However, crop yields do not correlate with total SOM, first of all due to the associated competition for light, water and nutrients, but also because nutrient release from SOM is largely dependent on the fraction of SOM that is biologically active (Barrios et al., 1996a). Aware of the competitive effects in simultaneous systems, research effort shifted to rotational crop-fallow systems as these are easier to understand and still part of farmers' reality. Efforts to identify biologically active fractions of SOM have shown that the amount of $\mathrm{N}$ in organic matter that is not physically protected and associated with soil particles, that is light fraction $\mathrm{N}$ that floats on water or solutions of densities below $1.1 \mathrm{~g} \mathrm{~cm}^{-3}$ (Meijboom et al., 1995), can be used as a sensitive measure of differences in SOM among cropping systems (Barrios et al., 1996a) as it correlates with whole soil N mineralization (Barrios et al., 1996b). Planted tree fallows significantly modified light fraction SOM when compared to a continuous unfertilized maize control; total SOM, however, was not affected (Barrios et al., 1997). Furthermore, while the amount of $\mathrm{N}$ in the light fraction correlated with maize yield, the quantity of light fraction SOM did not, thus highlighting the importance of organic input quality in soil $\mathrm{N}$ availability (Barrios et al., 1998). Key attributes of trees with the highest potential to increase soil $\mathrm{N}$ availability include the ability to fix nitrogen and litter with low (lignin+polyphenol)/nitrogen ratio that results in fast decomposition rates (Barrios et al., 1997). Additionally, planted tree fallow studies in which SOM fractionation and sequential $\mathrm{P}$ fractionation were conducted on the same soil samples showed that the amount of $\mathrm{P}$ in the light fraction could serve as sensitive indicators of the "readily available" soil-P pool (Phiri et al., 2001). Planted tree fallows, therefore, have been successfully used to regenerate degraded soils in Africa and Latin America in areas where population pressure on land is reduced (Kwesiga et al., 1999; Barrios et al., 2005).

With trees as the primary point of differentiation between agroforestry and agriculture and range management, the specific aspects of perenniality imply a different sampling in space and time of soil functions (Nair et al., 1999; van Noordwijk et al., 2004). Trees tend to be deeper rooted (with many noticeable exceptions; van Noordwijk et al., 1996) and sample a much larger horizontal area, challenging traditional plot-based research despite all efforts at trenching-off plots. The net effect (positive or negative) for a farmer of inclusion of trees in an agricultural system depend on A) total resource capture (TotCapt), B) harvest index of resources captured (HarvIndex), C) losses to other environmental compartments of resources not harvested (Loss), D) economic value of the resources harvested (Value) and costs of losses to the environment (Cost), E) the expenditure of labour and other inputs at going price (Price) and F) possible changes in land value ( $\Delta$ LandValue):

NetBenefit $=$ TotCapt ${ }^{*}$ HarvIndex * Value - Loss ${ }^{*}$ Cost - Inputs ${ }^{*}$ Price $+\Delta$ LandValue

Research has tried to dissect this by relating A to tree architecture, phenology and growth rate, potentially independent of $\mathrm{B}$ and $\mathrm{D}$, which are the focus of tree domestication and tree improvement efforts, alongside value chain economics. Aspect $\mathrm{E}$, the labour requirements of keeping the competitive aspects of trees under control while benefitting from the positive contributions to local 
nutrient cycles, proved to be a major challenge for the once-popular hedgerow intercropping systems. Meanwhile aspect $\mathrm{C}$ has gained importance with current refocus on greenhouse gas emissions, alongside erosion and leaching losses of soil particles and solutes. Aspect F may still be underresearched.

After a period of intensive research at process level on total resource capture, the conditions where 'over-yielding' of mixtures involving trees are fairly well established, while the effects of trees on losses by erosion and greenhouse gas emissions have been quantified for a range of situations(van Noordwijk et al., 2004). The interactions between trees and soil biota have been well explored in terms of mycorrhiza and earthworms (as reviewed later in this chapter), but a large part of the soil biological spectrum is open for further discovery. Science-based perspectives on bio-economic modeling can be compared with farmer preferences and knowledge, in the joint design of new management systems.

With depletion of agricultural soils due to nutrient export beyond the replenishment by fertilizer identified as a key challenge of farming (van Noordwijk, 1999), especially in Africa (Stoorvogel and Smaling, 1990; Cobo et al., 2010), considerable effort has been directed in the use of trees as 1) sources of biologically fixed nitrogen (Hairiah et al., 2000; Mafongoya et al., 2006), 2) recyclers and safety-nets of nutrients from deeper layers (van Noordwijk and Cadisch, 2002), and 3) converters of less-processed nutrient sources, such as rock phosphate. However, farm level nutrient budgets (Shepherd et al., 1996a; Shepherd and Soule, 1998) cautioned that agroforestry can result in large nutrient extractions in product removals while pointing to opportunities for nutrient imports through livestock feeds. The potential for tree fallows to re-capture leached nitrate held in the subsoil on anion exchange surfaces was demonstrated (Jama et al., 1998; Shepherd et al., 2000; 2001), and also the ability to reallocate some of the soil P into more labile P-pools (Hoang Fagerström et al., 2002; Schroth et al. 2003; Rao et al. 2004)). While a number of technical solutions have emerged that still are worth further testing (Akinnifesi et al., 2007), no silver bullets have emerged that revolutionize farming under the constraints of high nutrient exports and low economic feasibility of input use. As an alternative direction, the shift to tree crops with high economic value per unit harvested product has proven to be more successful.

Complementing the process and modeling approaches, new efforts are currently being made to efficiently describe the spatial variation in soil properties, in the hope that this can lead to better targeting of sustainable land management practices, while allowing for monitoring at real scale how soil properties change in response to land use (UNEP, 2012a; www.aricasoils.net). A major challenge for any quantification of 'impact' is the counterfactual: what conditions could be expected without the intervention that is evaluated for impact? Any comparison of current soil conditions under two land use systems must account for possible a priori differences between the locations where the two systems developed. This requires understanding of the existing variation in the landscape, local knowledge of conditions, preferences for specific parts of the landscape for specific land uses and ability to implement preferences (Hoang et al., 2013). There are some examples of tightly controlled designs for assessing changes in soil conditions in landscapes for forest transitions (Awiti et al., 2008) and exclosures (Vagen et al., 2008). 


\section{From process hypotheses and plot-level experiments to synthetic tree-soil-crop interaction models and management of filter functions}

Research on soil-tree-crop interactions in agroforestry have focused on growth resources sharing between trees and crops mediated by soil with the hypotheses of trees creating favorable microclimate and soil modifications for the associated crops. The findings have shown that trees on farms provide services to agriculture by contributing to (1) extended growing season by keeping the landscape covered with vegetation, (2) regulating water flows to the benefit of crops and ground water recharge, and (3) soil regeneration, carbon sequestration and nutrient cycling (ICRAF, 2013). However, the potential benefits depend on complex spatial and temporal interactions between the biological, physical, hydrological and climatic components of the system (Rao et al., 1998; Ong et al., 2013). Such interactions change with time as trees are getting larger together with the processes that affect the soil which are governed by the root systems to a larger extent (Lott et al., 2000a,b), but also by the tree phenology (Broadhead et al., 2003a,b; Muthuri et al., 2005). Finally, management practices also affect these interactions like the tree density and vegetation cover, the use of fires to clear the land (Ketterings et al., 2002; Rodenburg et al., 2003; van Noordwijk et al., 2008), the pruning of tree crown or root (Bayala et al., 2008b, 2013; Coulibaly et al., 2014), and the maintenance of pruned biomass, crop residue and litter as mulching (Rodenburg et al., 2003; Agus et al., 2004; Fonte at al., 2010; Malmer et al., 2004; Coulibaly et al., 2014).

While tree species vary in rooting architecture and root biomass, tree roots can extend to deeper soil layers compared to those occupied by the crop roots. They may therefore take up water from the groundwater even though there is evidence of trees taking up water from the top soil layers as well depending on the species and its root systems (Ong et al., 2014). Nevertheless, it is good to mention that there is no direct relationship between tree water extraction and fine root density as decreasing water potential also play a role (Radersma and Ong, 2004). The effects of the increase of $\mathrm{CO}_{2}$ and temperature as a result of climate change on change of soil carbon storage were reported to be contradictory, calling for more investigations to separate the effect of increase $\mathrm{C}$ and that of possible changes in root and rhizosphere (van Noordwijk et al., 1998). In mixed agroforestry systems, the use of isotopes has helped to disentangle the contributions of the components and revealed larger contribution of the C3 plants (trees) to soil carbon in comparison with the annuals (Jonsson, 1995; Bayala et al., 2006; 2014). As the tree root can go down deep, they can also lift up water and together with it nutrients that leached below the reach of crops. They can act as a safety net to capture nutrients leached from the topsoil and redistribute them to the soil surface (Rowe et al., 1999; Buresh et al., 2004). Such mechanism was reported to improve $\mathrm{N}$ use efficiency (Rowe et al., 2001). In addition, the estimates of water volume lifted/redistributed can represent up to $30 \%$ of the daily evapotranspiration (Burgess et al., 1999; Bayala et al., 2008a). According to these authors, this has a number of ecophysiological implications, e.g. maintaining fine root viability and avoidance of drought, while affecting some of the soil processes such as increase soil water and soil biota activity.

Some synthetic analyses of published data using meta-analysis have also helped understanding in which circumstances soil improvement translates into better crop production (Sileshi et al., 2010a; Bayala et al., 2012). Another review and meta-analysis by Sileshi et al. (2010b) showed that spatial heterogeneity in savannah vegetation was a result of termite mounds being fertility spots in the landscape enriched in clay, carbon, nitrogen, calcium, magnesium and potassium. 
The field investigations have helped generating a wealth of information on the processes in isolation but failed to reveal which one was the most prominent. A solution to this problem has been the development of a modeling phase which tried to synthesize the generated information to reveal the most limiting factors and processes for the production of the associated crops. For instance, simulations using WaNuLCAS revealed that the decrease in Zea mays growth near Grevillea robusta water due to lower soil water content that resulted in a decreased P diffusion (Radersma et al., 2008).

Similarly, water was found to be the most limiting nutrient under Vitellaria paradoxa while it was $\mathrm{P}$ under Parkia biglobosa (Bayala et al., 2008b). For planning adaptation, WaNuLCAS was also used by Coulibaly et al. (2014) to evaluate the effects of different management options (tree density, tree pruning, mulching and root pruning) on Sorghum bicolor production under future climate scenarios. There is a certain number of other models (APSIM, HiSafe, HyPAR, SCUAF, etc.) but they all have their limitations, which are inherent to models (over-simplification), or due to our poor understanding of the processes involved in soil-tree-crop interactions or to both (Matthews et al., 2004). If combining field investigations and modeling has helped to generate some scientific advances, there are still some methodological challenges in determining the "parkland effect" (effect of a group of trees on biodiversity, microclimate, etc.), the tradeoffs and synergies between and among goods and services, and how to boost the provisioning of ecosystems services Boffa et al., 2000).

Empirical research on agroforestry was initially largely built on the agronomic traditions of replicated field trials with plots in which a border zone was excluded from yield measurements to minimize lateral interactions between plots. Root research on trees, however, revealed that for many trees the lateral expansion can be multiples of the canopy height (van Noordwijk et al., 1996), and much of the experimental evidence need to be interpreted with caution. It is possible that 'control' plots were effectively mined by tree roots from neighboring plots, the performance on such plots enhanced by external nutrient capture, and hence the contrast between plots with and without trees magnified. Digging (deep) trenches around plots brings only temporary relief, as tree root systems can within a year occupy the space. Van Roode (2000) found in a well-designed, replicated field trial on various types of hedgerows as erosion control strategies, that the underlying variability of the hill slope with respect to infiltration capacity had a major effect on what was measured as overland flow at plot level, and the effectiveness of hedgerows as filters depended on the position of measurement. Much of the subsequent research relied on understanding spatial variability on the field, rather than on controlled experiments. Cohen et al. (2005) found for a landscape in Kenya that after a substantial effort to spatially parameterize the Universal Soil Loss Equation (USLE), the model correctly classified only $38 \%$ of sites into three degradation classes and the model sensitivity for delineating regions of severe degradation was only $28 \%$. Local calibration with ground data could increase the correctly classified sites to $54 \%$, but without expectation that a modified model would be valid elsewhere. Verbist et al. (2010) found little spatial agreement between prediction of different models (including modified USLE approaches), but also concluded that for the coffee dominated landscape in Lampung (Indonesia), in-field erosion was not the major determinant of river sediment transport. Overland sediment flows were partially filtered, while paths used for motorbike transport, roads and shallow landslides contributed sediment directly to the river. Sediment and soil transport issues appeared to have different determinants at every scale between a soil pedon, a plot, a hill-slope, a small and a large catchment. The fractal dimension that characterizes net sediment transport with a length scale to the power 1.5-1.6 (van Noordwijk et al., 1998c; Ranieri et al., 2004) was found to have a parallel in the social organization of watershed management institutions (Swallow et al., 2002). There has been little accompanying work on the economic costs of soil erosion and benefits of agroforestry. Cohen et al. (2006) estimated ecological-economic costs of soil erosion in Kenya using emergy analysis at 
different scales and found costs at the national level to be equivalent to the value of agricultural exports or electricity production.

A further step in the scientific understanding of agroforestry came when lateral resource capture was seen not only as a challenge to research aimed at defining technology for 'homogenous' conditions, but as an important aspect of real-world agroforestry, especially in the mixed stands typical of smallholdings, where edge planting of 'aggressive' trees may imply that half of the nutrients are scavenged off farm. This perspective on lateral resource capture aligned with the analysis of hedgerows of trees and naturally vegetated strips on sloping land. Rather than defining a uniform technology, science helped articulate a perspective on a range of niches in a diverse farming environment, with variation in tree properties that can be understood in and used in fine-tuning farmer decisions to plant, prune, manage, harvest and/or remove (van Noordwijk et al., 2004).

\section{Trees and other soil biota: Old tree root channels, earthworms, mycorrhiza, rhizobia and nematodes}

Trees live above as well as belowground. Soil structure is a key determinant of root development and root function, as well as for other soil biota. Soil compaction as a consequence of agricultural use and/or overgrazing is both a symptom of soil (mis)management as well as a cause of declining primary productivity. The importance of this, however, varies with the rainfall regime and climate zone. Macroporosity of soils, the class of pores most easily compacted, is essential for saturated hydraulic conductivity and the ability of soils to handle intense rain without overland flow and ensuing erosion. Macroporosity in the field is linked to texture (cracking clay soils), decayed tree root channels (van Noordwijk et al., 1991), the impact of deeply burrowing earthworms (Hairiah et al., 2006), and possibly other soil biota. Measurement of infiltration in the field typically shows lognormal distributions, with a small fraction of points having one or two orders of magnitude higher infiltration rates. The question of how such infiltration hot-spots at field scale operates during extreme rain events cannot be easily assessed from current measurement techniques, as much depends on their subsoil connectivity to landscape-level drainage systems. Agroforestry can influence the continuous formation of macroporosity through the provision of leaf litter feeding earthworms, and at another time scale, the formation of decaying tree root channels. At the level of mesoporosity the tendency of soils to form aggregates is strongly influenced by soil-ingesting soil biota (Fonte et al., 2010) and by fungal hyphae associated with mycorrhiza (Kuyper et al., 2004). Attribution of biological activity associated to soil structure modification is not a trivial exercise, but a methodological approach using Near Infrared Spectrometry (NIR) allowed the separation of soil aggregates produced by soil invertebrates and roots living in the same soil (Velasquez et al., 2007).

Vertical and horizontal water transport through and over the surface of soils is, however, a 'communicating vessels' problem with strong trade-offs. If water flows over the surface it may cause erosion, but it reduces the problem of leaching - and vice versa. A more detailed examination of bypass flow, however, made clear that macroporosity can drain excess water without much effect on solute transport in mesopores, especially where the latter benefit from physico-chemical ion adsorption acting as additional safety net (Suprayogo et al., 2002). Later versions of the WaNuLCAS model (van Noordwijk et al., 2011) have included such processes and allow the dynamics of soil structure, bypass flow and root-based safetynets for leaching nutrients to be quantified. 
In Burkina Faso, with yearly rainfall ranging from 570 to $1180 \mathrm{~mm}$, groundwater recharge was simulated to be equivalent of $2-14 \%$ of the total gross water input. A combination of the measurement and modeling of drainage and transpiration in agroforestry parkland revealed that intermediate density of trees (5-25 trees ha ${ }^{-1}$ based on the assumption that 100 to $0 \%$ of transpired water is coming from below $1.5 \mathrm{~m}$ depth) can maximize groundwater recharge while at higher stockings there was a tradeoff between tree cover and available water (Ilstedt et al., 2014).

The soil environment may well host and interact with the most complex biological community once we account for scale (Susilo et al., 2004). Soil biota (e.g. microbes, invertebrates), mostly contained in the upper few decimeters of soil are extremely diverse and make important contributions to a wide range of ecosystem services that are essential to the sustainable function of natural and managed ecosystem (Barrios, 2007; Sileshi et al., 2007). New high-throughput DNA profiling techniques are supporting efforts to assess the global distribution of soil biota and the relationship of below-ground biodiversity to above-ground biodiversity (Wu et al., 2011). Soil biota directly influence soil fertility by mobilizing nutrients (Kuyper et al., 2004), and form soil structure (Fonte et al., 2010) increasing water infiltration and soil $\mathrm{C}$ storage, and decreasing soil erosion. Therefore, in order to understand the distribution and diversity of soil organisms and how they respond to disturbance, be it agricultural practices or climate change, it is necessary to monitor the soil and environmental quality which is required for sustaining land health in agricultural ecosystems (Barrios et al., 2012b). Strategies for maintaining native biota of farm soils, such as mycorrhizal inoculum potential, are generally preferable to inoculation strategies (Shepherd et al., 2006b). Recent global studies show that preservation of plant biodiversity is crucial to maintain multiple ecosystem functions like nutrient cycling, plant productivity and carbon storage, and also to buffer negative effects of climate change (Maestre et al., 2012). Slash and mulch agroforestry systems show greater abundance of soil macro fauna than the native forest suggesting that maintenance of soil cover with organic materials of different qualities promotes favorable conditions for soil biological activity (Pauli et al., 2011). Comparison of adjacent agricultural plots with and without trees show that tree presence increases abundance of several groups of soil biota (Barrios et al., 2012b). Further, greater soil biological activity occurs near trees but effect is greater for some tree species than for others (Pauli et al., 2010) and this is likely related to differences in plant functional traits (Ordonez et al., 2014). Trees can be considered as "hot spots" of biological activity and play a major role in maintaining and promoting soil biological activity responsible for many of these functions that underpin soil-mediated ecosystem services (Barrios et al., 2012b). Farmer perspectives and knowledge on soil biota together with scientific knowledge contribute to better understanding of tree-soil biota interactions in time and space that would allow designing diverse cropping systems that can sustain multiple functions required for the adequate provision of ecosystem services (Swift et al., 2004; Giller et al., 2005; Sileshi et al., 2008; Pauli et al., 2012).

\section{Soil carbon dynamics and greenhouse gas emissions from agroforestry systems}

The ASB program was the first to establish a cross-continental network of sites with consistent measurement of above- and belowground carbon stocks of forests and forest-derived land uses in the humid tropics, as synthesized by Palm et al. (2005). A review of the way soil carbon stocks vary with soil type, elevation (temperature) and land cover introduced the concept of C-reference values and associated soil carbon deficits (van Noordwijk et al., 1997), taking the natural forest soils with the 
same texture, mineralogy, $\mathrm{pH}$ and elevation as basis for a pedotransfer function. The empirical relationships between texture and soil carbon content were aligned with the assumptions and process descriptions of the Century model; attempts to measure the 'functional' fractions represented in the model remained partially unsuccessful, however (Sitompul et al., 2000). Analysis of carbon dynamics in aggregate fractions (Albrecht and Kandji, 2003) could not be directly linked to fully functional carbon balance models.

Carbon stocks are additive and allow area-based scaling, making it straightforward to scale from plot to landscape (van Noordwijk et al., 2002), once the scale-dependent patterns of spatial variation are known. The high spatial variability of soil carbon, coupled to costs of sampling and analysis and challenges in attributing differences to cause-effect chains, make it unlikely that soil carbon, when assessed with current standard methods, can become part of carbon projects (van Noordwijk, 2014). More optimistic perspectives related to methodological improvements will be discussed below. A further challenge to such inclusion is the observation that a 'soil carbon transition curve', with recovery following degradation, can be observed in response to agricultural intensification, and without specific soil carbon interventions (van Noordwijk et al., 2014). Rather than being a primary target for interventions and finance as part of climate change mitigation, soil carbon should be of interest from the perspective of buffering of soil water and nutrient content, as part of farmer resilience and climate change adaptation (Verchot et al., 2007).

The early measurements on nitrous oxide and methane emissions in relation to tropical land use change suggested that such fluxes will generally be small relative to the greenhouse gas effect of tropical forest conversion through changes in (mostly aboveground) carbon stocks. Specific for the use of $\mathrm{N}_{2}$ fixing shrubs and trees in agroforestry, where $\mathrm{N}$ rich mulch is left on the soil surface without incorporation into the soil, high emissions of nitrous oxide are possible and were measured in shaded coffee systems (Verchot et al., 2006). In terms of net greenhouse gas effects the jury is out to determine whether biological $\mathrm{N}_{2}$ fixation by trees is friend or foe (Rosenstock et al., 2014); the likely answer is that it depends on how and where such trees are used.

\section{Soil/Land health surveillance}

ICRAF's work on low cost rapid soil characterization using diffuse reflectance spectroscopy began with the use of field spectroscopy in combination with Landsat imagery to trace sources of soil erosion in Lake Victoria (Shepherd and Walsh, 2000). This early work, using the visible-near-infrared (VNIR) wavelength range, also showed the potential for using soil reflectance to measure management induced changes in soil quality in long-term trials (Shepherd and Walsh, 2000). This was later demonstrated at landscape scale in land use change studies in Madagascar (Vagen et al., 2006) and along a tropical forest-cropland chrono-sequence in Kenya (Awiti et al., 2008). A scheme for the use of spectral libraries as a tool for building risk-based approaches to soil evaluation was demonstrated for a diverse library of over 1000 topsoils from eastern and southern Africa, including development of spectral diagnostic tests for screening soils with respect to critical soil fertility limits (Shepherd and Walsh, 2002). The global applicability of soil spectroscopy was further demonstrated using a global soil library based on archived samples at the US National Soil Survey Center using VNIR (Brown et al., 2006) and for available samples from the International Soil Reference and Information Centre global archives using mid-infrared spectroscopy (Terhoeven-Urselmans et al., 2010). 
Infrared spectroscopy uses a different set of principles than conventional soil fertility tests and provides a single multiple-utility measure of soil production potential and response to management (Shepherd \& Walsh, 2007; Nicota et al., 2014). With IR, soils can be characterised in a single 30second measure that requires no chemicals, only light. The shapes of infrared spectra respond to the basic molecular structure of mineral and organic composition of soils and their interactions. It is the organic-mineral composition that determines soil functional properties, including a soil's ability to retain and supply different nutrients and water, nitrogen mineralisation capacity, soil charge characteristics, soil structural stability and ability to resist soil erosion, and amount of soil organic carbon in different pools and its protection. Although calibration to conventional soil tests has been used as an intermediate step, the ultimate concept behind the spectral approach is to calibrate soil and crop responses to management directly to infrared spectra and completely by-pass the need for conventional soil tests (Shepherd et al., 2007).

The ability to derive spectral indicators of soil fertility was demonstrated in several studies. Vagen et al., (2006) successfully calibrated soil condition classes, based on ten commonly used agronomic indicators of soil fertility, to both soil reflectance measured in the laboratory and Landsat TM reflectance, which permitted mapping of the index. The spectral index also related to $\delta 13 \mathrm{C}$ dynamics associated with historic land use changes, similar to Awiti et al. (2008) who were able to spectrally discriminate forest-cropland chronosequence classes. A similar approach was successfully used for spectral prediction and mapping of soil fertility classes in Mali (UNEP, 2012a), while Muhati et al. (2011) calibrated principal components of soil fertility variables to spectra to assess the prevalence of soil fertility constraints on farm fields in Kenya.

Several studies have shown strong relationships between observed or measured soil erosion in the field and laboratory measured soil spectra. Cohen et al. (2005) was able to spectrally discriminate ground visual observations of three ordinal erosion classes in the Kenya Nyando river basin with validation accuracies of 78\%. De Graffenreid and Shepherd (2009) used a similar approach in the Kenya Saiwa river basin and obtained validation accuracies of $72 \%$, with additional validation of the erosion classes using soil ${ }^{137} \mathrm{Cs}$ concentration data. Walsh and Shepherd (2006) developed an erosiondeposition index as a tool to rapidly screen soils in the Nyando river basin into eroded, intact, or depositional soil classes based on a spectral distance index using sediment spectra as a reference library. The spectral index was validated using ${ }^{137} \mathrm{Cs}$ analysis and soil spectra were also used to interpolate ${ }^{210} \mathrm{~Pb}$ concentration in sediment cores. The combined data allowed a sediment budget for the basin to be constructed as well as the historic time trends in soil erosion from 1900.

Soil spectroscopy was shown to be able to predict various soil carbon fractions and their mineralization rates. Mid-infrared (MIR) spectroscopy was used to predict the concentration of organic carbon fractions present in a diverse set of Australian and Kenyan soils (Janik et al., 2007). The coefficient of determination of measured versus predicted data $\left(\mathrm{r}^{2}\right)$ ranged from 0.97 and 0.73 for total organic carbon, particulate organic carbon, and charcoal carbon. Soil spectra were also shown to predict carbon mineralization rates from different soil physical fractions in two contrasting soil types (Mutuo et al., 2006). At the same sites, mid-infrared spectra were used to interpret functional groups to help elucidate biogeochemical mechanisms that determine the fate of carbon inputs in soils and organic matter stabilization by aggregates (Verchot et al., 2011). Kamau-Rewe et al. (2011) found that removing the mineral soil spectra in Alfisols, obtained from heated soils, did not improve spectral calibrations of soil organic carbon, indicting the robustness of the spectral method.

Reflectance spectroscopy was shown to be useful for predicting organic resource quality for soil and livestock management based on nitrogen, lignin and soluble polyphenol concentrations (Shepherd et al., 2003, Vanlauwe et al., 2005). Validation $\mathrm{r}^{2}$ of $>0.8$ were obtained for prediction of in vitro dry 
matter digestibility (IVDMD) and $\mathrm{C}$ and $\mathrm{N}$ mineralization for a diverse range of crop and tree residues of varying quality (Shepherd et al., 2005; Tscherning et al., 2005; 2006). NIR for determination of crude protein content in cowpea (Vigna unguiculata) leaves was also demonstrated (Towett et al., 2013a).

The role of infrared spectroscopy enabling an evidence-based diagnostic surveillance approach to agricultural and environmental management in developing countries was articulated by Shepherd and Walsh (2007). This paper outlined a diagnostic surveillance approach to assessing agricultural and environmental problems in developing countries, based on the scientific principles used in public health surveillance, where surveillance is the main mechanism for determining public health policy and practice. Infrared spectroscopy was proposed as a rapid screening tool for assigning samples to case or reference and allowing characterization of the health of systems at scale using populationbased sampling. The diverse range of applications of infrared spectroscopy in agriculture and environment was reviewed.

In response to the need for objective, quantitative and cost-efficient methods for assessment of land health to justify, target and prioritize investments, the diagnostic surveillance principles were taken further to form a conceptual framework for wide-area soil and land health surveillance (Shepherd et al., 2008; 2015; UNEP, 2012a). Land health is defined as the capacity of land to sustain delivery of ecosystem services, and is a prerequisite for wise ecosystem management and sustainable development. The soil spectroscopy methods were key to enabling this approach by providing a soil analytical tool that could be applied cost-effectively at scale. Land health surveillance is hinged on systematic georeferenced field observations based on probability sampling (Land Degradation Surveillance Framework - LDSF; UNEP 2012a; Vagen et al., 2013a), so that inferences can be made back to the target area sampled. Georeferenced soil spectral estimates of soil properties are statistically modeled to remote sensing covariates so that the models can be applied back to every pixel on the satellite imagery to provide digital maps of soil properties. The report and accompanying atlas (UNEP, 2012b) illustrate the land health surveillance concepts with a case study in the West Africa Sahel, presenting results on regional remote sensing studies of historical changes in vegetation growth and rainfall patterns in the area, indicating land degradation trends, and on field level assessment of land degradation in Mali. This combination of principles and scientific and technical advances formed the basis for the Africa Soil Information Service (AfSIS).

ICRAF played a foundational role in the establishing the Africa Soil Information Service. The project has implemented the first ever probability sample of African land health and soils, based on a set of $60100-\mathrm{km}^{2}$ sentinel sites, providing a baseline for future monitoring of soil health changes (Sanchez et al., 2009; www.africasoils.net). Spectral measurements were performed on all samples, while conventional reference measurements were done on a $10 \%$ random subsample (Vagen et al., 2010). A centralized Africa soil spectral prediction service is being piloted based on Bayesian Additive Regression Trees. This will allow spectrometer users to submit batches of spectra online and obtain predictions of soil properties with uncertainties given for each sample. Samples that are spectral outliers or have large prediction error can be submitted to the ICRAF laboratory for characterization and adding to the calibration library. This service could drastically reduce the need for conventional soil testing.

In support of this initiative, ICRAF established a globally unique, Soil-Plant Spectral Diagnostics Laboratory, which focuses on analyzing soils using only light (infrared, x-ray, laser). The laboratory established Fourier Transform near- and mid-infrared spectroscopy as a foundation for calibration transfer across a network of spectrometers. The light-based technologies have been extended to: benchtop x-ray diffraction for mineralogical analysis; total x-ray fluorescence for total element 
analysis in soils (Towett et al., 2013b), plants and water; handheld x-ray fluorescence spectroscopy; and laser diffraction particle size analysis for dry and wet aggregate stability, for which standard operating procedures are available at: http://worldagroforestry.org/research/land-health/spectraldiagnostics-laboratory. The laboratory supports a soil spectroscopy network spanning 10 African countries, to which it provides scientific and technical backstopping, including on-site training. Extensive support has been provided towards the establishment of the Ethiopia Soil Information System (http://www.ata. gov.et/projects/ethiopian-soil-information-system-ethiosis/). To enable easier access to soil spectral calibration techniques, ICRAF has developed the soil.spec software package in $\mathrm{R}$ (http://cran.r-project.org/web/ packages/soil.spec/soil.spec.pdf) and now runs an international soil spectroscopy training course.

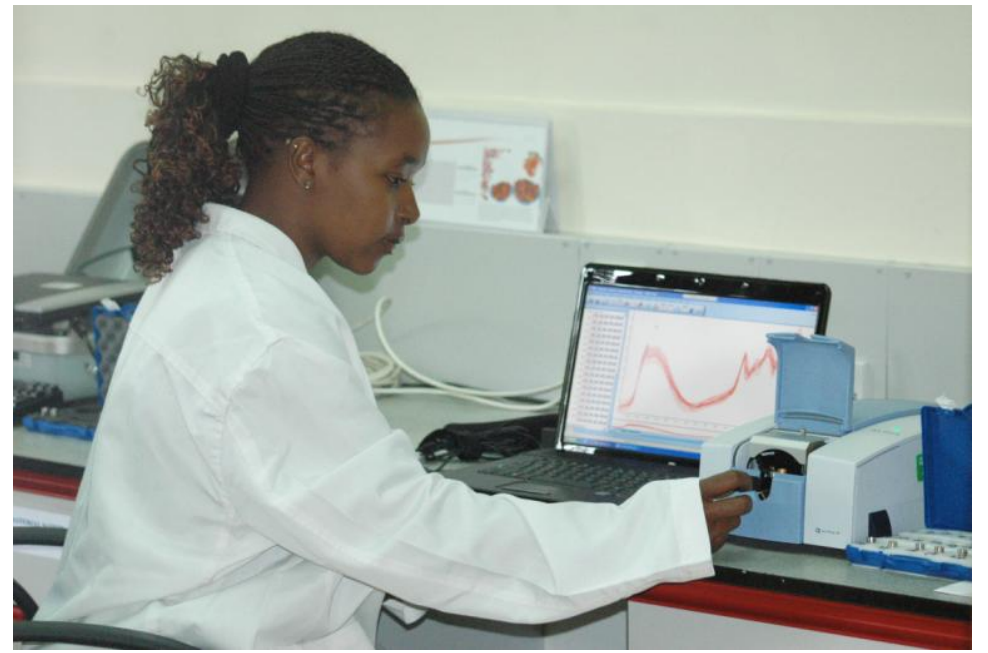

Figure 2. Portable mid-infrared spectrometer being used for rapid characterization of soil samples.

Land health surveillance approaches supported by soil spectroscopy are being applied in a number of sustainable land management projects in 10 African countries and in the CGIAR pan-tropical sentinel sites initiative. These include applications such as mapping soil carbon in rangelands (Vagen et al., 2012), monitoring and degradation prevalence and soil functional properties in Ethiopia (Vagen et al., 2013b), and studying patterns in soil faunal and microbial activity in landscapes (Barrios et al., 2012). Soil spectroscopy has also been used to characterize patterns of variability in soil fertility in smallholder farming systems (Tittonell et al., 2005; 2008; 2010; 2013). Current applications include a pilot on integrating monitoring of soil fertility on farms into the World Bank Living Standards Measurement Study and soil monitoring in an integrated monitoring system for ecosystem services in agricultural landscapes (www.vitalsigns.org). Soil spectroscopy is also now being used by two private soil testing services in Kenya.

Systematic application of land health surveillance has potential to generate improved understanding and predictive ability of agricultural systems and natural resources at multiple scales, and improve intervention decision planning and impact assessment. Technological advances will lead to reliable handheld and mobile phone based spectrometers and put the technology in the hands of farmers. The CGIAR can play an important role in building up centralized, online spectral calibration and advisory services. Digital mapping techniques based on Bayesian spectral-spatial one-step modeling with prediction uncertainties generated are already in development. These scientific and technical advances are paving the way for a new paradigm of predictive agronomy and crop breeding, whereby response trials are co-located with soil spectral measurements and remote sensing observations. This could greatly enhance our ability to predict and map uncertainty in responses to soil and crop management and perhaps by-pass conventional soil tests. While the biophysical understanding of soil management 
has received much attention, there is need for much more attention to demonstrating the economic value of soil ecosystem services and improved soil management practices, and to better integrating soil information into decision making processes (e.g. Herrick et al., 2013; Rosenstock et al., 2013; http://africasoils.net/labs/mapping/use-case-“make-agro-input-recommendations"-2/).

\section{The challenge of demonstrating development impact through soil changes}

While the balance that draws us towards direct solutions for urgent problems of poverty, food security and environmental destruction, swings back periodically to the equally pressing needs of scientific rigor and generalizable public goods, ICRAF as a CGIAR research centre has a long history of trying to satisfying all and debating where the best position is along the curve described. Rather than choosing one point, it is important that the balance can swing.

From a time when "packaged technology" was seen as a generic answer to local development challenges of many farmers in many places we have moved forward to a greater appreciation of diversity. Spatial variability and diversity has often been seen as a problem, in that it does not allow simplistic perspective on scaling up to perform. As 'homogeneity' has often been used as a siteselection criterion for field experiments, as it increases the chance of "statistically significant" treatment effects to be seen with practically feasible levels of replication, scientists reviewing experimental evidence have a biased view of the world (van Noordwijk and Wadman, 1992).

Technologies that were carefully packaged by scientists are generally unpacked by farmers - who will adopt the parts they like, and find new ways around the parts they don't (Sanchez et al., 2001;

Sanchez, 2002; Ajayi et al., 2007; Place et al., 2002). Having learnt from this experience, science and extension developed a more modest approach to presenting a basket of options, with attention to risk management and the question of how many eggs should be put into each basket (van Noordwijk et al., 1994).

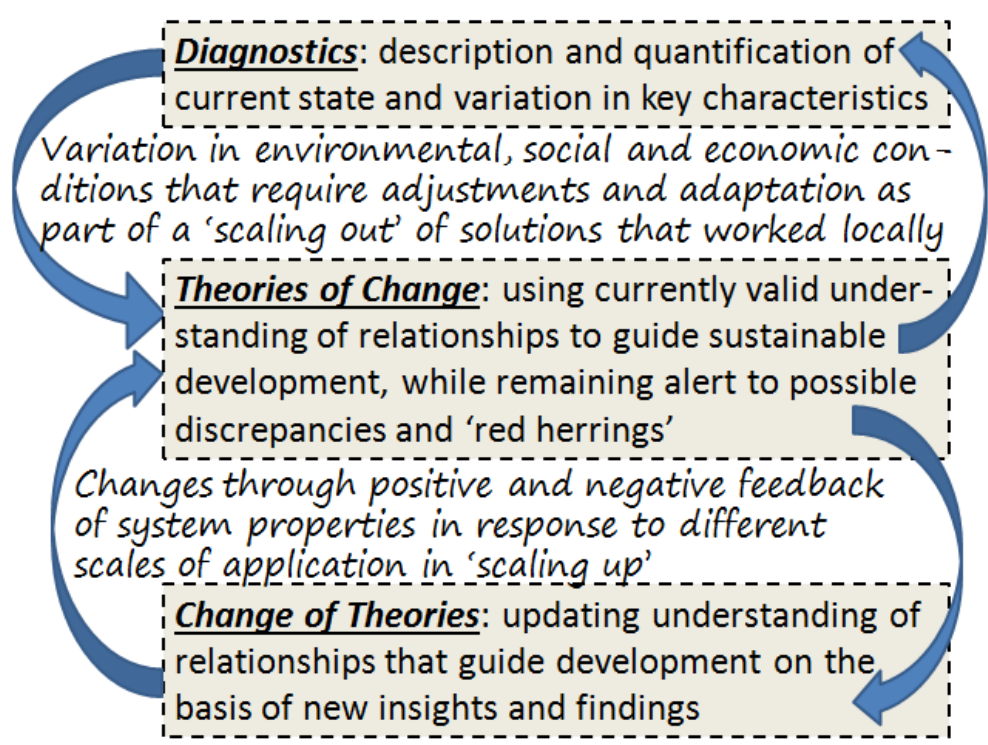

Figure 3. Key concepts of research in development, that require continued diagnostics as part of monitoring and evaluation and sentinel approaches, explicit theories of change that address both variation in circumstances encountered in 'scaling out' and changes in dynamic properties as a response of 'scaling up', and that may lead to change of theory. 
Unfortunately, the funders of international agricultural research are fascinated by the numbers of farmers and the area of land that can be claimed to be benefit from 'improved practices' and are linking funding decisions to a 'beauty contest' among alternative programs judged on claims to impact. A direction that offers that one 'can eat development cake' and have good science as well, is seen to be in 'research in development' (Coe et al., 2014), with a focus on fine-tuning the baskets of options to what might have a chance to be accepted, and an equal attention to what and how farmers choose and why they do so - with social and gender stratification replacing the abstract standard farmer perceived before. This gives an even greater weight to taking local knowledge seriously: not only does it point to empirical experience from which formal science can learn; it also suggests a language in which scientific findings can be communicated back, alongside the baskets of options. Science in that perspective can be useful by testing and validating simple decision trees at component level (Vanlauwe et al., 2005).

Change in soil properties tends to be slow compared to aboveground changes, and this 'slow variable' characteristics has consequences for impact studies. On one hand it implies that changes in soil conditions, whether negative (depletion, degradation) or positive (restoration), once set in motion can be expected to have long lasting, negative or positive, effects that add to the importance of observed trends. On the other hand, the slow change, combined with high inherent spatial variability of soils, makes it difficult to obtain convincing evidence of any change. A simple spreadsheet model presented in Hoang et al. (2013) illustrates how a sampling of soil conditions found under different land use systems can lead to strongly biased conclusions about "effects of land use on the soil" if it does not account for the degree to which local variation on soil conditions informed land use patterns in the first place (Fig. 4).
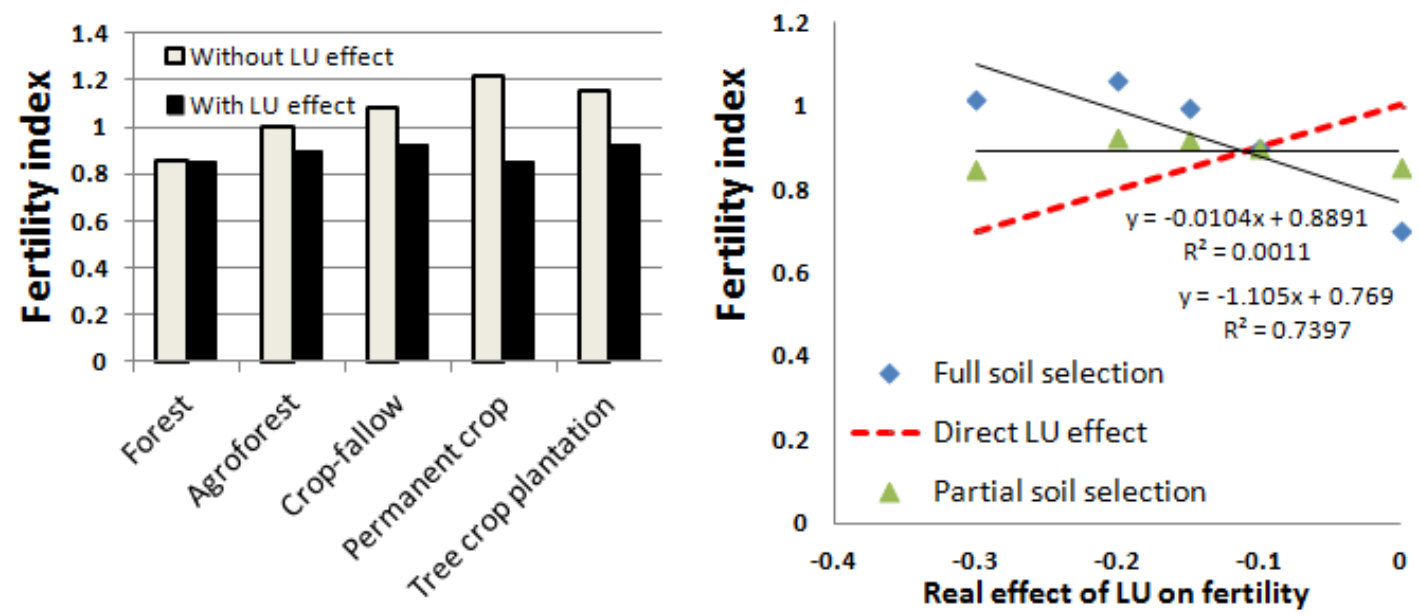

Figure 4. Illustration of the way land use (LU) effects on soil properties, together with the preferential positioning of land uses in specific parts of a landscape, influence survey results, with the possibility of apparent effects having opposite signs to real ones (Hoang et al., 2013)

Positive or negative changes in soil conditions in response to business as usual development, modified by specific development interventions impact on many stakeholders. The most obvious ones are literally downstream, as the soil controls the switch between overland flow, with associated flashiness of rivers, and infiltration for slower 'interflow' in saturated soils and groundwater replenishment in other situations. The contrasting interests between 'water harvesting', where overland flow is to be stimulated and used, versus beneficiaries of infiltration has been noted before. The recent discourse on 
'rainbow water' suggests that there are also 'downwind' stakeholders, whose interest may differ from those downstream (van Noordwijk et al., 2014b).

\section{Conclusion: Soil as fundamental to a big issues agenda with attention to local knowledge}

As stated in the introduction, a balance needs to be struck between research to gain a deeper scientific understanding of the complex systems that agroforestry deals with at pedon, farm, landscape and global scales, and efforts to share more effectively what we do know but what could be used more effectively.

Further progress in soil science at the World Agroforestry Centre will have to address the multiple agendas of global articulation of the ambitions for sustainable development, with growing evidence that forms of agroforestry can support many of the goals set (Mbow et al., 2014b), national green economy ambitions with land uses that minimizes damage or restores soils after phases of degradation (Mbow et al., 2014a), and local farmer preferences and choices. The complex involvement of multiple actors in what is perceived to be 'sustainable' (Bernard et al., 2014) suggests that a close linkage of technical and social expertise will remain important for impact-oriented fundamental soil science in agroforestry. 


\section{References}

Agus, F., Farida, Van Noordwijk, M. (Eds), 2004. Hydrological Impacts of Forest, Agroforestry and Upland Cropping as a Basis for Rewarding Environmental Service Providers in Indonesia. Proceedings of a workshop in Padang/Singkarak, West Sumatra, Indonesia. 25-28 February 2004. ICRAF-SEA, Bogor, Indonesia

Ajayi, O.C., Akinnifesi, F.K., Sileshi, G., Chakeredza, S. 2007. Adoption of renewable soil fertility replenishment technologies in the southern African region: Lessons learnt and the way forward. In Natural Resources Forum Vol. 31(4), 306-317.

Akinnifesi, F.K., Makumba, W., Sileshi, G., Ajayi, O.C., Mweta, D. 2007. Synergistic effect of inorganic N and $\mathrm{P}$ fertilizers and organic inputs from Gliricidia sepium on productivity of intercropped maize in Southern Malawi. Plant and Soil 294, 203-217.

Albrecht, A., Kandji, S.T. 2003. Carbon sequestration in tropical agroforestry systems. Agriculture, Ecosystems and Environment, 99, 15-27.

Awiti, A.O., Walsh, M.G., Shepherd, K.D., Kinyamario J. 2008. Soil condition classification using infrared spectroscopy: a proposition for assessment of soil condition along a tropical forest-cropland chronosequence. Geoderma 143, 73-84.

Barrios, E. 2007. Soil biota, ecosystem services and land productivity. Ecological Economics 64, 269-285.

Barrios, E., Trejo, M.T. 2003. Implications of local soil knowledge for integrated soil management in Latin America. Geoderma 111, 217-231.

Barrios, E., Buresh, R.J., Sprent, J.I. 1996a. Organic matter in soil particle size and density fractions from maize and legume cropping systems. Soil Biology \& Biochemistry 28, 185-193.

Barrios, E., Buresh, R.J., Sprent, J.I. 1996b. Nitrogen mineralization in density fractions of soil organic matter from maize and legume cropping systems. Soil Biology \& Biochemistry 28, 1459-1465.

Barrios, E., Kwesiga, F., Buresh, R.J., Sprent, J.I. 1997. Light fraction soil organic matter and available nitrogen following trees and maize. Soil Science Society of America Journal 61, 826-831.

Barrios, E., Kwesiga, F., Buresh, R.J., Sprent, J.I., Coe, R. 1998. Relating preseason soil nitrogen to maize yield in tree legume-maize rotations. Soil Science Society of America Journal 62, 1604-1609.

Barrios, E., Cobo, J.G., Rao, I.M., Thomas, R.J., Amezquita, E., Jimenez, J.J., Rondon, M.A. 2005. Fallow management for soil fertility recovery in tropical Andean agroecosystems in Colombia. Agriculture, Ecosystems and Environment 110, 29-42.

Barrios, E., Delve, R.J., Bekunda, M., Mowo, J., Agunda, J., Ramisch, J., Trejo, M.T., Thomas, R.J. 2006. Indicators of soil quality: A South-South development of a methodological guide for linking local and technical knowledge. Geoderma 135, 248-259.

Barrios, E., Coutinho, H.L., Medeiros, C.A. 2012a. InPaC-S: Participatory Knowledge Integration on Indicators of Soil Quality - Methodological Guide. World Agroforestry Centre (ICRAF), Embrapa, CIAT. 178 p.

Barrios, E., Sileshi, G.W., Shepherd, K., Sinclair, F. 2012b. Agroforestry and soil health: linking trees, soil biota and ecosystem services. In: Wall, D.H. (Ed.). The Oxford Handbook of Soil Ecology and Ecosystem Services. Oxford University Press, Oxford, UK. pp. 315-330.

Bayala, J., Balesdent, J., Marol, C., Zapata, F., Teklehaimanot, Z., Ouedraogo, S.J. 2006. Relative contribution of trees and crops to soil carbon content in a parkland system in Burkina Faso using variations in natural 13C abundance. Journal Nutrient Cycling in Agroecosystems 76, 193-201.

Bayala, J., Balesdent, J., Marol, C., Zapata, F., Teklehaimanot, Z., Ouedraogo, S.J. 2007. Relative contribution of trees and crops to soil carbon content in a parkland system in Burkina Faso using variations in natural 13C abundance. In Advances in Integrated Soil Fertility Management in sub-Saharan Africa: Challenges and Opportunities (pp. 161-169). Springer Netherlands.

Bayala J., Heng L. K., van Noordwijk M., Ouedraogo S.J. 2008a. Hydraulic Lift study in two native tree species of agroforestry parklands of West African dry savanna. Acta Oecologica 34, 370-378.

Bayala J., van Noordwijk M., Lusiana B., Kasanah N., Teklehaimanot Z., Ouedraogo S.J. 2008b. Separating the tree-soil-crop interactions in agroforestry parkland systems in Saponé (Burkina Faso) using WaNuLCAS. Advances in Agroforestry 4, 296-308. 
Bayala, J., Sileshi, G.W., Coe, R., Kalinganire, A., Tchoundjeu, Z., Sinclair, F., Garrity, D. 2012. Cereal yield response to conservation agriculture practices in drylands of West Africa: a quantitative synthesis. J Arid Environ 78, 13-25.

Bayala, J., Bazié, H.R., Sanou, J. 2013. Competition and facilitation-related factors impacts on crop performance in an agro-forestry parkland system in Burkina Faso. African Journal of Agricultural Research 8, 5303-5310.

Bayala J., Sanou J., Teklehaimanot Z., Kalinganire A., Ouédraogo S.J. 2014. Parklands for buffering climate risk and sustaining agricultural production in the Sahel of West Africa. Current Opinion in Environmental Sustainability 6, 28-34.

Bernard, F., van Noordwijk, M., Luedeling, E., Villamor, G.B., Gudeta, S., Namirembe, S. 2014 Social actors and unsustainability of agriculture. Current Opinion in Environmental Sustainability 6, 155-161.

Boffa, J. M., Taonda, S. B., Dickey, J. B., \& Knudson, D. M. (2000). Field-scale influence of karité (Vitellaria paradoxa) on sorghum production in the Sudan zone of Burkina Faso. Agroforestry Systems, 49(2), 153175.

Brown, D.J., Shepherd, K.D., Walsh, M.G., Dewayne Mays, M., Reinsch, T.G. 2006. Global soil characterization with VNIR diffuse reflectance spectroscopy. Geoderma, 132, 273-290.

Buresh, R.J., Tian, G. 1998. Soil improvement by trees in sub-Saharan Africa. In Directions in Tropical Agroforestry Research (pp. 51-76). Springer Netherlands.

Buresh, R.J., Sánchez, P.A., Calhoun, F., Hatfield, J., Bigham, J.M. 1996. Replenishing soil fertility in Africa. Soil Science Society of America.

Buresh, R.J., Rowe, E.C., Livesley, S.J., Cadisch, G., Mafongoya, P., van Noordwijk, M.., Ong, C.K. 2004. Opportunities for capture of deep soil nutrients. Below-ground interactions in tropical agroecosystems: concepts and models with multiple plant components, 109-125.

Burgess, S.S., Adams, M.A., Turner, N.C., Ong, C.K. 1998. The redistribution of soil water by tree root systems. Oecologia 115, 306-311.

Cannell, M.G.R., van Noordwijk, M., Ong, C.K. 1996. The central agroforestry hypothesis: the trees must acquire resources that the crop would not otherwise acquire. Agroforestry Systems 34, 27-31.

Cobo, J.C., Dercon, G., Cadisch, G. 2010. Nutrient balances in African land use systems across different spatial scales: A review of approaches, challenges and progress. Agriculture, Ecosystems and Environment 136, 115.

Coe, R., Sinclair, F., Barrios, E. 2014. Scaling up agroforestry requires research 'in' rather than 'for' development. Current Opinion in Environmental Sustainability 6, 73-77.

Cohen, M.J., Brown, M.T., Shepherd, K.D. 2006. Estimating the environmental costs of soil erosion at multiple scales in Kenya using emergy synthesis. Agriculture, Ecosystems and Environment 114, 249-269.

Cohen, M.J., Shepherd, K.D., Walsh, M.G. 2005. Empirical reformulation of the universal soil loss equation for erosion risk assessment in a tropical watershed. Geoderma 124, 235-252.

Coulibaly, Y.N., Mulia, R., Sanou, J., Zombre, N., Bayala, J., Kalinganire, A., van Noordwijk, M. 2014. Crop production under different rainfall and management conditions in agroforestry parkland systems in Burkina Faso: observations and simulation with WaNuLCAS model. Agroforestry Systems 88, 13-28.

Fonte, S.J., Barrios, E., Six, J. 2010. Earthworms, soil fertility and aggregate-associated soil organic matter dynamics in the Quesungual agroforestry system. Geoderma 155, 320-328.

Garrity, D.P., Soekardi, M., van Noordwijk, M., de la Cruz, R., Pathak, P.S., Gunasena, H.P.M., van So, N., Huijun, G. and Majid N.M., 1997. The Imperata grasslands of tropical asia: area, distribution and typology. Agroforestry Systems 36, 3-29

Giller, K.E., Bignell, D.E., Lavelle, P., Swift, M.J., Barrios, E., Moreira, F., van Noordwijk, M., Barois, I., Karanja, N., Huising, J. 2005. Soil biodiversity in rapidly changing tropical landscapes: scaling down and scaling up. In: Biological Diversity and Function in Soils (Eds. R.D. Bardgett, M.B. Usher, D.W. Hopkins), pp. 295-318. Cambridge University Press, Cambridge.

Hairiah, K., van Noordwijk, M., Cadisch, G. 2000. Crop yield, C and N balance of three types of cropping systems on an Ultisol in Northern Lampung. NJAS-Wageningen Journal of Life Sciences 48, 3-17.

Hairiah, K., Sulistyani, H., Suprayogo, D., Purnomosidhi, P., Widodo, R.H., van Noordwijk, M. 2006. Litter layer residence time in forest and coffee agroforestry systems in Sumberjaya, West Lampung. Forest Ecology and Management 224, 45-57. 
Herrick, J.E., Urama, K.C., Karl, J.W., Boos, J., Johnson, M.V., Shepherd, K.D., et al. 2013. The global LandPotential Knowledge System (LandPKS): Supporting evidence-based, site-specific land use and management through cloud computing, mobile applications, and crowdsourcing. Journal of Soil and Water Conservation $68,5 \mathrm{~A}-12 \mathrm{~A}$.

Hoang Fagerström, M.H., Nilsson, S.I., van Noordwijk, M., Thai Phien, Olsson, M., Hansson,A., Svensson, C. 2002. Does Tephrosia candida as fallow species, hedgerow or mulch improve nutrient cycling and prevent nutrient losses by erosion on slopes in northern Vietnam? Agriculture, Ecosystems \& Environment 90, 291 304.

Hoang, M.H., Joshi, L., van Noordwijk. M. 2013. Participatory landscape appraisal (PaLA). In: van Noordwijk M, Lusiana B, Leimona B, Dewi S, Wulandari D (eds). Negotiation-support toolkit for learning landscapes. Bogor, Indonesia. World Agroforestry Centre (ICRAF) Southeast Asia Regional Program. p. 16-21.

ICRAF. 2006. Improved land management in the Lake Victoria basin: final report on the TransVic project. Occasional Paper 07. World Agroforestry Centre ICRAF, Nairobi.

Ilstedt, U., Bargués Tobella. A., Bazié, H.R., Bayala, J., Verbeeten, E., Nyberg, G., Sanou, J., Benegas, L., Murdiyarso, D., Laudon, H., Sheil, D., Malmer, A. 2014. Intermediate tree cover can maximize groundwater recharge. (manuscript).

Jama, B., Buresh, R.J., Ndufa, J.K., Shepherd, K.D. 1998. Vertical distribution of roots and soil nitrate: tree species and phosphorus effects. Soil Science Society of America Journal 62, 280-286.

Janik, L.J., Skjemstad, J.O., Shepherd, K.D., Spouncer, L.R. 2007. The prediction of soil carbon fractions using mid-infrared-partial least square analysis. Journal of Australian Soil Research 45, 73-81.

Joshi, L., Shrestha, P. K., Moss, C., Sinclair, F. L., Noordwijk, M. V., Cadisch, G., \& Ong, C. K. 2004a. Locally derived knowledge of soil fertility and its emerging role in integrated natural resource management. In: van Noordwijk, M., Cadisch, G. and Ong, C.K. (Eds.) Belowground Interactions in Tropical Agroecosystems, CAB International, Wallingford (UK), pp 17-39

Joshi, L., Schalenbourg, W., Johansson, L., Khasanah, N., Stefanus, E., Fagerström, M.H., van Noordwijk, M. 2004b. Soil and water movement: combining local ecological knowledge with that of modellers when scaling up from plot to landscape level. In: van Noordwijk, M., Cadisch, G. and Ong, C.K. (Eds.) Belowground Interactions in Tropical Agroecosystems, CAB International, Wallingford (UK). pp. 349-364.

Kamau-Rewe, M., Rasche, F., Cobo, J.G., Dercon, G., Shepherd, K.D., Cadisch, G. 2011. Generic prediction of soil organic carbon in Alfisols using diffuse reflectance Fourier transformed mid-infrared spectroscopy. Soil Science Society of America Journal 75, 2358-2360.

Ketterings, Q.M., van Noordwijk, M., Bigham, J.M. 2002. Soil phosphorus availability after slash-and-burn fires of different intensities in rubber agroforests in Sumatra, Indonesia. Agriculture, Ecosystems and Environment 92, 37-48.

Kuyper, T.W., Cardoso, I.M., Onguene, N.A., Murniati, V.N.M. 2004. Managing mycorrhiza in tropical multispecies agroecosystems. Below-ground interactions in tropical agroecosystems, concepts and models with multiple plant components. CABI Publishing, Wallingford, 243-261.

Kwesiga, F.; Franzel, S.; Place, F.; Phiri, D.; Simwanza, C.P. 1999. Sesbania sesban improved fallows in eastern Zambia: Their inception, development and farmer enthusiasm. Agroforestry Systems 47, 49-66.

Lott J.E., Howard S.B., Black C.R., Ong C.K. 2000a. Long term productivity of a Grevillea robusta-based agroforestry system in Kenya. I. Tree growth. Forest Ecology and Management 139, 175-186.

Lott J.E., Howard S.B., Black C.R., Ong C.K. 2000b. Long term productivity of a Grevillea robusta-based agroforestry system in Kenya II. Crop growth and system productivity. Forest Ecology and Management 139, 187-201.

Maestre, F.T., Quero, J.L., Gotelli, N.J., Escudero, A., et al. 2012. Plant species richness and ecosystem multifunctionality in global drylands. Science 335 (6065), 214-218.

Mafongoya, P.L., Kuntashula, E., Sileshi, G. 2006. Managing soil fertility and nutrient cycles through fertilizer trees in southern Africa. Biological Approaches to Sustainable Soil Systems, Taylor \& Francis, 273-289.

Malmer, A., van Noordwijk, M., Bruijnzeel, L.A., Bonell, M. 2004. Effects of shifting cultivation and forest fire. In The joint UNESCO International Hydrological Programme (IHP)-International Union of Forestry Research Organizations (IUFRO) symposium and workshop, Forest-water-people in the humid tropics: past, present and future hydrological research for integrated land and water management, Universiti Kebangsaan Malaysia, 30 July-4 August 2000. (pp. 533-560). Cambridge University Press. 
Matthews, R., van Noordwijk, M., Gijsman, A.J., Cadisch, G., 2004. Models of below-ground interactions: their validity, applicability and beneficiaries. In: van Noordwijk, M., Cadisch, G., Ong, C.K. (Eds.) Belowground Interactions in Tropical Agroecosystems, CAB International, Wallingford (UK). pp. 41-60

Mbow, C., Neufeldt, H., van Noordwijk, M., Minang, P., Kowero, G., Luedeling, E. 2014a. Agroforestry solutions to address climate change and food security challenges in Africa. Current Opinion in Environmental Sustainability 6, 61-67.

Mbow, C., van Noordwijk, M., Prabhu, R., Simons, A.J. 2014b. Knowledge gaps and research needs concerning agroforestry's contribution to sustainable development goals in Africa. Current Opinion in Environmental Sustainability 6, 162-170.

Meijboom, F.W., Hassink. J., van Noordwijk, M. 1995 Density fractionation of soil macro-organic matter using silica suspensions. Soil Biology and Biochemistry 27, 1109-1111.

Minang, P.A., van Noordwijk, M., Kahurani, E. (Eds.). 2014. Partnership in the Tropical Forest Margins: a 20Year Journey in Search of Alternatives to Slash-and-Burn. Nairobi, Kenya. ICRAF 241 pp.

Muhati, S.I., Shepherd, K.D., Gachene, C.K., Mburu, M.W., Jones, R., Kironchi, G.O., Sila, A. 2011. Diagnosis of Soil Nutrient Constraints in Small-scale Groundnut (Arachis hyopaea L.) Production Systems of Western Kenya Using Infrared Spectroscopy. Journal of Agricultural Science and Technology A: 111-127.

Murdiyarso D., van Noordwijk M., Wasrin, U.R., Tomich T.P., Gillison A.N. 2002. Environmental benefits and sustainable land-use options in the Jambi transect, Sumatra, Indonesia. Journal of Vegetation Science 13, 429-438.

Muthuri, C.W., Ong, C.K., Mati, B.M., van Noordwijk, M. 2005. Modelling the effects of leafing phenology on growth and water use by selected agroforestry tree species in semi-arid Kenya. Land and Water Resources Research 4, 1-11.

Mutuo, P.K., Shepherd, K.D., Albrecht, A., Cadisch, G. 2006. Prediction of carbon mineralization rates from different soil physical fractions using diffuse reflectance spectroscopy. Soil Biology and Biochemistry 38, 1658-1664.

Nair, P.R., Buresh, R.J., Mugendi, D.N., Latt, C.R. 1999. Nutrient cycling in tropical agroforestry systems: myths and science. Agroforesty in sustainable agricultural systems. CRC Press, Lewis Publ., Boca Raton, FL.

Ndufa, J.K., Shepherd, K.D. Buresh, R.J., Jama, B. 1999. Nutrient uptake and growth of young trees in a Pdeficient soil: Tree species and phosphorus effects. Forest Ecology and Management 122, 231-241.

Nocita, M., Stevens, A., van Wesemael, B., Brown, D.J., Shepherd, K.D., Towett, E., Vargase, R., Montanarella, L. 2014. Soil spectroscopy: an opportunity to be seized. Global Change Biology. Article first published online. 21 Jun 2014, DOI: 10.1111/gcb.12632

Ong C., Black C.R., Wilson J., Muthuri C., Bayala J., Jackson N.A. 2014. Agroforestry: hydrological impacts. Book Chapter in Encyclopedia of Agriculture and Food Systems (in press).

Ordonez, J.C., Luedeling, E., Kindt, R., Tata, H.L., Harja, D., Jamnadass, R., van Noordwijk, M. 2014. Constraints and opportunities for tree diversity management along the forest transition curve to achieve multifunctional agriculture. Current Opinion in Environmental Sustainability 5, 54-60.

Palm, C.A., van Noordwijk, M., Woomer, P.L., Alegre, J.C., Arevalo, L., Castilla, C.E., Sitompol, S.M. 2005. Carbon losses and sequestration after land use change in the humid tropics. Slash-and-burn agriculture: the search for alternatives. Columbia University Press, New York.

Pauli, N., Oberthur, T., Barrios, E., Conacher, A. 2010. Fine-scale spatial and temporal variation in earthworm surface casting activity in agroforestry fields, western Honduras. Pedobiologia 53, 127-139.

Pauli, N.. Barrios, E., Conacher, A.J.. Oberthur, T. 2011. Soil macrofauna in agricultural landscapes dominated by the Quesungual Slash-and-Mulch Agroforestry System, western Honduras. Applied Soil Ecology 47, 119-132.

Pauli, N., Barrios, E., Conacher, A.J., Oberthur, T. 2012. Farmer knowledge of the relationships among soil macrofauna, soil quality, and tree species in a small holder agroforestry system of western Honduras. Geoderma 189-190, 186-198.

Phiri, S., Barrios, E., Rao, I.M., Singh, B.R. 2001. Changes in soil organic matter and phosphorus fractions under planted fallows and a crop rotation system on a Colombian volcanic-ash soil. Plant and Soil 231, 211223.

Place, F., Franzel, S., DeWolf, J., Rommelse, R., Kwesiga, F., Niang, A., Jama, B. 2002.Agroforestry for Soilfertility Replenishment: Evidence on Adoption Processes in Kenya and Zambia. In: C. Barrett, F. Place, A. 
Aboud (Eds.), Natural resources management in African agriculture: understanding and improving current practices, CABI Publ, 155-180.

Radersma, S., Ong, C. K. 2004. Spatial distribution of root length density and soil water of linear agroforestry systems in sub-humid Kenya: implications for agroforestry models. Forest ecology and management 188, 77-89.

Radersma, S., Lusiana, B., van Noordwijk, M. 2005. Simulation of soil drying induced phosphorus deficiency and phosphorus mobilization as determinants of maize growth near tree lines on a Ferralsol. Field Crops Research 91, 171-184.

Ranieri, S.B.L., Stirzaker, R., Suprayogo, D., Purwanto, E., de Willigen, P., van Noordwijk, M., 2004. Managing movements of water, solutes and soil: from plot to landscape scale. In: van Noordwijk, M., Cadisch, G., Ong, C.K. (Eds.) Belowground Interactions in Tropical Agroecosystems, CAB International, Wallingford (UK). pp. 329-347.

Rao, I.M., Barrios, E., Amezquita, E., Friesen, D.K., Thomas, R.J., Oberson, A., Singh, B.R. 2004. Soil Phosphorus dynamics, acquisition and cycling in Crop-Pasture-Fallow systems in Low Fertility Soils: A review from Latin America. Modeling Nutrient Management in Tropical Cropping Systems. ACIAR Proceedings No.114, pp. 126-134

Rao, M.R., Nair, P.K.R., Ong, C.K. 1998. Biophysical interactions in tropical agroforestry systems. In Directions in Tropical Agroforestry Research (pp. 3-50). Springer Netherlands.

Rodenburg, J., Stein, A., van Noordwijk, M., Ketterings, Q.M. 2003. Spatial variability of soil pH and phosphorus in relation to soil run-off following slash-and-burn land clearing in Sumatra, Indonesia. Soil and Tillage Research 71, 1-14.

Rosenstock, T.S., Mpanda, M., Rioux, J., Aynekulua, E., Kimaro, A.A., Neufeldt, H., Shepherd, K.D., Luedeling, E. 2014. Targeting conservation agriculture in the context of livelihoods and landscapes. Agriculture Ecosystems \& Environment 187, 47-51.).

Rosenstock, T.S., Tully, K.L., Arias-Navarro, C., Neufeldt, H., Butterbach-Bahl, K., Verchot, L.V. 2014. Agroforestry with $\mathrm{N}_{2}$-fixing trees: Sustainable development's friend or foe? Current Opinion in Environmental Sustainability 6, 15-21.

Rowe, E.C., van Noordwijk, M., Suprayogo, D., Hairiah, K., Giller, K.E., Cadisch, G. 2001. Root distributions partially explain ${ }^{15} \mathrm{~N}$ uptake patterns in Gliricidia and Peltophorum hedgerow intercropping systems. Plant and Soil 235, 167-179.

Sanchez, P.A. 1987. Soil productivity and sustainability in agroforestry systems. In: H.A., Steppler, P.K.R., Nair (Eds) Agroforestry: a decade of development, International Council for Research in Agroforestry, Nairobi pp 205-223.

Sanchez, P.A. 1995. Science in agroforestry. Agroforestry systems 30, 5-55.

Sanchez, P.A. 2002. Soil fertility and hunger in Africa. Science (Washington) 295, 2019-2020.

Sanchez, P.A., Jama, B.A., Vanlauwe, B., Diels, J., Sanginga, N., Merckx, R. 2001. Soil fertility replenishment takes off in East and Southern Africa. Integrated plant nutrient management in sub-Saharan Africa: from concept to practice, 23-45.

Sanchez, P.A., Shepherd, K.D., Soule, M.J., Place, F.M., Buresh, R.J., Izac, A.M.N., Woomer, P.L. 1997. Soil fertility replenishment in Africa: An investment in natural resource capital. Replenishing soil fertility in Africa pp 1-46.

Santoso, D., Adiningsih, S., Mutert, E., Fairhurst, T., van Noordwijk, M. 1996. Soil fertility management for reclamation of Imperata grasslands by smallholder agroforestry. Agroforestry Systems 36, 181-202.

Schroth, G., Lehmann, J,; Barrios, E. 2003. Soil nutrient availability and acidity. In Trees, Crops and Soil Fertility: Concepts and Research Methods. (G.Schroth and F.L.Sinclair, eds). Pp. 93-130. CABI.

Shepherd, K.D., Walsh, M.G. 2000. Sensing soil quality: the evidence from Africa. Natural Resource Problems, Priorities and Policies Programme Working Paper 2000-1. International Centre for Research in Agroforestry, Nairobi.

Shepherd, K.D., Walsh, M.G. 2002. Development of reflectance spectral libraries for characterization of soil properties. Soil Science Society of America Journal 66, 988-998.

Shepherd, K.D., Walsh, M.G. 2007. Infrared spectroscopy—enabling an evidence-based diagnostic surveillance approach to agricultural and environmental management in developing countries. Journal of Near Infrared Spectroscopy 15, 1-19. 
Shepherd, K.D., Ohlsson, E., Okalebo, J.R. Ndufa, J.K. 1996a. Potential impact of agroforestry on soil nutrient balances at the farm scale in the East African Highlands. Fertilizer Research 44, 87-99

Shepherd, K.D., Jefwa, J., Wilson, J., Ndufa, J.K., Ingelby, K., Mbuthia, K.W. 1996b. Infection potential of farm soils as mycorrhizal inocula for Leucaena leucocephala. Biology and Fertility of Soils 22, 16-21.

Shepherd, K.D., Ndufa, J.K., Ohlsson, E., Sjogren, H., Swinkels, R. 1997. Adoption potential of hedgerow intercropping in maize-based cropping systems in the highlands of western Kenya. I. Background and agronomic evaluation. Experimental Agriculture 33, 197-223.

Shepherd, K.D., Soule, M.J. 1998. Economic and ecological impacts of soil management on west Kenyan farms: a dynamic simulation model. Agriculture, Ecosystems and Environment 71, 131-146.

Shepherd, G., Buresh, R.J. Gregory, P.J. 2000. Land use effects the distribution of soil inorganic nitrogen in smallholder production systems in Kenya. Biology and Fertility of Soils 31, 348-355.

Shepherd, G., Buresh, R.J., Gregory, P.J. 2001. Inorganic soil nitrogen distribution in relation to soil properties in smallholder maize fields in the Kenyan highlands. Geoderma 101, 87-103.

Shepherd, K.D., Palm, C.A., Gachengo, C.N., Vanlauwe, B. 2003. Rapid characterization of organic resource quality for soil and livestock management in tropical agroecosystems using near infrared spectroscopy. Agronomy Journal 95, 1314-1322.

Shepherd, K.D., Shepherd, G. Walsh, M.G. 2015. Land health surveillance and response: a framework for evidence-informed land management. Agricultural Systems 132: 93-106.

Shepherd, K.D., Vagen, T.G., Gumbricht, T. Walsh, M.G. 2008. Land Degradation Surveillance: Quantifying and Monitoring Land Degradation. In Sustainable Land Management Sourcebook. The World Bank, Washington DC, pp $141-147$.

Sileshi, G.W., Kuntashula, E., Matakala, P., Nkunika, P.O. 2008. Farmers' perceptions of tree mortality, pests and pest management practices in agroforestry in Malawi, Mozambique and Zambia. Agroforestry Systems 72, 87-101.

Sileshi, G.W., Nyeko, P., Nkunika, P.O., Sekematte, B.M., Akinnifesi, F.K., Ajayi, O.C. 2009. Integrating ethno-ecological and scientific knowledge of termites for sustainable termite management and human welfare in Africa. Ecology and Society 14, 48

Sileshi, G., Akinnifesi, F.K., Ajayi, O.C., Chakeredza, S., Kaonga, M., Matakala, P.W. 2007. Contributions of agroforestry to ecosystem services in the Miombo eco-region of eastern and southern Africa. African Journal of Environmental Science and Technology 1, 68-80.

Sileshi, G., Akinnifesi, F.K., Debusho, L.K., Beedy, T., Ajayi, O.C., Mong'omba, S. 2010. Variation in maize yield gaps with plant nutrient inputs, soil type and climate across sub-Saharan Africa. Field Crops Res. 11, $1-13$.

Sileshi, G.W., Arshad, M.A., Konaté, S., Nkunika, P.O. 2010. Termite-induced heterogeneity in African savanna vegetation: mechanisms and patterns. Journal of Vegetation Science 21, 923-937.

Sinclair, F.L., Joshi, L. 2000. Taking local knowledge about trees seriously. Forestry Forest Users and Research: New ways of learning. ETFRN Wageningen Netherlands, 45-58.

Sitompul, S.M., Hairiah, K., Cadisch, G., van Noordwijk, M. 2000. Dynamics of density fractions of macroorganic matter after forest conversion to sugarcane and woodlots, accounted for in a modified Century model. NJAS-Wageningen Journal of Life Sciences 48, 61-73.

Sjögren, H., Shepherd, K.D., Karlsson, A. 2010. Effects of improved fallow with Sesbania sesban on maize productivity and Striga hermonthica infestation in Western Kenya. Journal of Forestry Research 21, 379386.

Soule, M.J., Shepherd, K.D. 2000. A regional economic analysis of phosphorus replenishment for Vihiga Division, western Kenya. Agricultural Systems 64, 83-98.

Stoorvogel, J.J., Smaling, E.M.A. 1990. Assessment of Soil Nutrient Depletion in Sub- Saharan Africa, 1983 2000. Winand Staring Centre for Integrated Soil and Water Research (SC-DLO), Wageningen, The Netherlands.

Suprayogo, D., van Noordwijk, M., Hairiah, K., Cadisch, G. 2002. The inherent 'safety-net'of an Acrisol: Measuring and modelling retarded leaching of mineral nitrogen. European Journal of Soil Science 53, 185 194. 
Susilo, F.X., Neutel, A.M., van Noordwijk, M., Hairiah, K., Brown, G., Swift, M.J., Ong, C.K. 2004. Soil biodiversity and food webs. In: van Noordwijk, M., Cadisch, G., Ong, C.K. (Eds.) Belowground Interactions in Tropical Agroecosystems, CAB International, Wallingford (UK), 285-307.

Swallow, B.M., Garrity, D.P., van Noordwijk, M. 2002. The effects of scales, flows and filters on property rights and collective action in watershed management. Water policy 3, 457-474.

Swift, M.J., Shepherd, K.D. 2007. Saving Africa's soils: science and technology for improved soil management in Africa. Joint NEPAD, ICRAF, TSBF-CIAT Publication. World Agroforestry Centre, Nairobi.

Swift, M.J., Izac, A.M., van Noordwijk, M. 2004. Biodiversity and ecosystems services in agricultural landscapes - are we asking the right questions? Agriculture, Ecosystems and Environment 104, 113-134.

Swinkels, R.A., Franzel, S.C., Shepherd, K.D., Ohlsson, E.L., Ndufa, J.K 1997. The economics of short rotation improved fallows: evidence from areas of high population density in western Kenya. Agricultural Systems $55,99-121$.

Tata, H.L., van Noordwijk, M., Summerbell, R., Werger, M.J.A. 2010. Limited response to nursery-stage mycorrhiza inoculation of Shorea seedlings planted in rubber agroforest in Jambi, Indonesia. New Forests $39,51-74$.

Terhoeven-Urselmans, T., Vagen, T.G., Spaargaren, O., Shepherd, K.D. 2010. Prediction of soil fertility properties from a globally distributed soil mid-infrared spectral library. Soil Science Society of America Journal 74, 1792-1799.

Tittonell, P., Vanlauwe, B., Leffelaar, P.A., Shepherd, K.D., Giller, K.E. 2005. Exploring diversity in soil fertility management of smallholder farms in western Kenya II. Within-farm variability in resource allocation, nutrient flows and soil fertility status. Agriculture, Ecosystems and Environment 110, $166-184$.

Tittonell P., Shepherd, K.D., Vanlauwe, B., Giller, K.E. 2008. Unravelling the effects of soil and crop management on maize productivity in smallholder agricultural systems of western Kenya--An application of classification and regression tree analysis. Agriculture, Ecosystems and Environment 123, 137-150.

Tittonell, P., Muriuki, A., Shepherd, K.D., Mugendi, D., Kaizzi, K.C., Okeyo, J., Vanlauwe, B. 2010. The diversity of rural livelihoods and their influence on soil fertility in agricultural systems of East Africa-A typology of smallholder farms. Agricultural systems 103, 83-97.

Tittonell, P., Muriuki, A., Klapwijk, C.J., Shepherd, K.D., Coe, R., Vanlauwe, B. 2013. Soil Heterogeneity and Soil Fertility Gradients in Smallholder Agricultural Systems of the East African Highlands. Soil Science Society of America Journal 77, 525-538.

Towett, E.K., Alex, M., Shepherd, K.D., Polreich, S., Aynekulu, E., Maass, B.L. 2013a. Applicability of nearinfrared reflectance spectroscopy (NIRS) for determination of crude protein content in cowpea (Vigna unguiculata) leaves. Food Science and Nutrition 1, 45-53.

Towett, E.K., Shepherd, K.D, Cadisch, G. 2013b. Quantification of total element concentrations in soils using total X-ray fluorescence spectroscopy (TXRF). Science of the Total Environment 463-464, 374-388.

Tscherning, K.2 Barrios, E., Lascano, C.E., Peters, M., Schultze-Kraft, R. 2005. Effects of sample post-harvest treatment on aerobic decomposition and anaerobic in-vitro digestion of tropical legumes with contrasting quality. Plant and Soil 269, 159-170.

Tscherning, K., Lascano, C.E., Barrios, E., Schultze-Kraft, R., Peters, M. 2006. The effect of mixing prunings of two tropical shrub legumes (Calliandra houstoniana and Indigofera zollingeriana) with contrasting quality on $\mathrm{N}$ release in the soil and apparent $\mathrm{N}$ degradation in the rumen. Plant and Soil 280, 357-368.

UNEP 2012a. Land Health Surveillance: An Evidence-Based Approach to Land Ecosystem Management. Illustrated with a Case Study in the West Africa Sahel. United Nations Environment Programme, Nairobi. http://www.unep.org/dewa/Portals/67/pdf/LHS_Report lowres.pdf

UNEP 2012b. Sahel Atlas of Changing Landscapes: Tracing trends and variations in vegetation cover and soil condition. United Nations Environment Programme, Nairobi. http://www.unep.org/dewa/Portals/67/pdf/

Sahel_Atlas_lowres.pdf

Vågen, T.G., Shepherd, K.D., Walsh, M. G. 2006. Sensing landscape level change in soil fertility following deforestation and conversion in the highlands of Madagascar using Vis-NIR spectroscopy. Geoderma 133, 281-294.

Vågen, T.G., Walsh, M.G., Shepherd, K.D. 2008. Potential for Carbon Storage through Rehabilitation of Degraded Lands in the Lake Baringo Basin. Report to UNDP.

Vågen, T.G., Shepherd, K.D., Walsh, M.G., Winowiecki, L., Desta, L.T., Tondoh, J.E. 2010. AfSIS Technical Specifications. Soil Health Surveillance. Version 1.0. World Agroforestry Centre ICRAF, Nairobi. 
Vågen, T.G., Davey, F.A., Shepherd, K.D. 2012. Land Health Surveillance: Mapping Soil Carbon in Rangelands. In P.K. Ramachandran Nair, D. Garrity (eds) Agroforestry - The Future of Global Land Use. Springer, Dordrecht, pp. 455-462.

Vågen, T.G., Winowiecki, L.A., Abegaz, A., Hadgu, K.M. 2013. Landsat-based approaches for mapping of land degradation prevalence and soil functional properties in Ethiopia. Remote Sensing of Environment 134, 266275.

Vågen, T.G., Winowiecki, L.A., Tondoh, J.E. 2013. The Land Degradation Surveillance Framework Field Guide. Version 4. World Agroforestry Centre ICRAF.

van Noordwijk, M. 1999. Nutrient cycling in ecosystems versus nutrient budgets of agricultural systems. Nutrient Cycles and Nutrient Budgets in Global Agro-ecosystems. CAB International, Wallingford, 1-26.

van Noordwijk, M. 2002. Scaling trade-offs between crop productivity, carbon stocks and biodiversity in shifting cultivation landscape mosaics: the FALLOW model. Ecological Modelling, 149, 113-126.

van Noordwijk, M. 2014 Avoided land degradation and enhanced soil C storage: is there a role for carbon markets? SCOPE Review of multiple benefits of soil organic carbon, CAB-International, Wallingford (UK).

van Noordwijk, M., Cadisch, G. 2002. Access and excess problems in plant nutrition. Plant and Soil 247, 25-39.

van Noordwijk, M., Lusiana, B. 1999. WaNuLCAS, a model of water, nutrient and light capture in agroforestry systems. In Agroforestry for Sustainable Land-Use Fundamental Research and Modelling with Emphasis on Temperate and Mediterranean Applications (pp. 217-242). Springer Netherlands.

van Noordwijk, M., Garrity, D.P., 1995. Nutrient use efficiency in agroforestry systems. In: Potassium in Asia: Balanced Fertilization to Increase and Sustain Agricultural Production. International Potash Institute, Basel, Switzerland. pp 245-279. http://worldagroforestry.org/regions/southeast_asia/publications? do=view pub detail\&pub no=PP0034-04

van Noordwijk, M., Wadman, W. 1992. Effects of spatial variability of nitrogen supply on environmentally acceptable nitrogen fertilizer application rates to arable crops. Netherlands Journal of Agricultural Science 40, 51-72.

van Noordwijk, M., Widianto, Heinen, M., Hairiah, K. 1991. Old tree root channels in acid soils in the humid tropics: important for crop root penetration, water infiltration and nitrogen management. Plant Soil 134, 3744.

van Noordwijk, M., Dijksterhuis, G., Van Keulen, H., 1994. Risk management in crop production and fertilizer use with uncertain rainfall: how many eggs in which baskets. Netherlands Journal of Agricultural Science 42, 249-269.

van Noordwijk, M., Lawson, G., Groot, J.J.R., Hairiah, K. 1996. Root distribution in relation to nutrients and competition. In: C.K. Ong and P.A. Huxley (Eds.). Tree-Crop Interactions - a Physiological Approach. CAB International, Wallingford. pp 319-364.

van Noordwijk, M., Hairiah, K., Partoharjono, S., Labios, R.V., Garrity, D.P. 1996. Food-crop-based production systems as sustainable alternatives for Imperata grasslands? Agroforestry Systems 36, 55-82.

van Noordwijk, M., Cerri, C., Woomer, P. L., Nugroho, K., Bernoux, M. 1997. Soil carbon dynamics in the humid tropical forest zone. Geoderma 79, 187-225.

van Noordwijk, M., Murdiyarso, D., Hairiah, K., Wasrin, U.R., Rachman, A., Tomich, T.P. 1998a. Forest soils under alternatives to slash-and-burn agriculture in Sumatra, Indonesia. In Soils of Tropical Forest Ecosystems (pp. 175-185). Springer Berlin Heidelberg.

van Noordwijk, M., van Roode, M., McCallie, E.L., Lusiana, B. 1998c. Erosion and sedimentation as multiscale, fractal processes: implications for models, experiments and the real world. In: F.P. de Vries, F. Agus, J. Kerr (Eds). Soil erosion at multiple scales: principles and methods for assessing causes and impacts, CAB International, Wallingford, UK, 223-253.

van Noordwijk, M., Hairiah, K., Woomer, P., Murdiyarso, DM. 1998b. Criteria and indicators of forest soils used for slash-and-burn agriculture and alternative land uses in Indonesia. The Contribution of Soil Science to the Development of and Implementation of Criteria and Indicators of Sustainable Forest Management, pp 137-154.

van Noordwijk, M., Martikainen, P., Bottner, P., Cuevas, E., Rouland, C., Dhillion, S.S. 1998. Global change and root function. Global Change Biology 4, 759-772.

van Noordwijk, M., Rahayu, S., Hairiah, K., Wulan, Y.C., Farida, A., Verbist, B. 2002. Carbon stock assessment for a forest-to-coffee conversion landscape in Sumber-Jaya (Lampung, Indonesia): from 
allometric equations to land use change analysis. Science in China series C Life Sciences, English edition 45(supp), 75-86.

van Noordwijk, M., Cadisch, G., Ong, C.K. (Eds.). 2004 Belowground Interactions in Tropical Agroecosystems, CAB International, Wallingford (UK), $580 \mathrm{pp}$.

van Noordwijk, M., Cadisch, G., Ong, C.K. 2004. Challenges for the next decade of research on below-ground interactions in tropical agroecosystems: client-driven solutions at landscape scale. In: van Noordwijk, M., Cadisch, G., Ong, C.K. (Eds.). 2004. Belowground Interactions in Tropical Agroecosystems, CAB International, Wallingford (UK). pp. 365-379.

van Noordwijk M., Mulyoutami, E., Sakuntaladewi, N., Agus, F. 2008. Swiddens in transition: shifted perceptions on shifting cultivators in Indonesia. Bogor, Indonesia. World Agroforestry Centre - ICRAF, SEA Regional Office. 48 p.

van Noordwijk, M., Lusiana, B., Khasanah, N., Mulia, R. 2011. WaNuLCAS version 4.0, Background on a Model of Water Nutrient and Light Capture in Agroforestry Systems. World Agroforestry Centre (ICRAF), Bogor, Indonesia.

van Noordwijk, M., Goverse, T., Ballabio, C., Banwart, S., Bhattacharyya, T., Goldhaber, M., Nikolaidis, N., Noellemeyer, E., Zhao, Y. 2014a. Soil organic carbon transition curves: reversal of land degradation through management of soil organic matter for multiple benefits. SCOPE Review of multiple benefits of soil organic carbon, CAB-International, Wallingford (UK).

van Noordwijk, M., Namirembe, S., Catacutan D.C., Williamson, D., Gebrekirstos, A. 2014b. Pricing rainbow, green, blue and grey water: tree cover and geopolitics of climatic teleconnections. Current Opinion in Environmental Sustainability 6, 41-47.

van Roode, M., 2000. The effects of vegetative barrier strips on surface runoff and soil erosion in Machakos, Kenya. A statistical versus a spatial modelling approach. $\mathrm{PhD}$ thesis, University of Utrecht (the Netherlands) $283 p$.

Vanlauwe, B., Gachengo, C., Shepherd, K., Barrios, E., Cadisch, G., Palm, C.A. 2005. Laboratory validation of a resource quality-based conceptual framework for organic matter management. Soil Science Society of America Journal 69, 1135-1145.

Velasquez, E., Pelosi, C., Brunet, D., Grimaldi, M., Martins, M., Rendeiro, A.C., Barrios, E., Lavelle, P. 2007. This ped is my ped: Visual separation and near infrared spectra allow determination of the origins of soil macroaggregates. Pedobiologia 51, 75-87.

Verbist, B., Poesen, J., van Noordwijk, M. Widianto, Suprayogo, D., Agus, F., Deckers, J. 2010. Factors affecting soil loss at plot scale and sediment yield at catchment scale in a tropical volcanic agroforestry landscape. Catena 80, 34-46.

Verchot, L.V., Hutabarat, L., Hairiah, K., van Noordwijk, M. 2006. Nitrogen availability and soil $\mathrm{N}_{2} \mathrm{O}$ emissions following conversion of forests to coffee in southern Sumatra. Global Biogeochem. Cycles, 20, GB4008, doi:10.1029/2005GB002469.

Verchot, L.V., van Noordwijk, M., Kandji, S., Tomich, T., Ong, C., Albrecht, A., Palm, C. 2007. Climate change: linking adaptation and mitigation through agroforestry. Mitigation and Adaptation Strategies for Global Change 12, 901-918.

Verchot, L.V., Dutaur, L., Shepherd, K.D., Albrecht, A. 2011. Organic matter stabilization in soil aggregates: Understanding the biogeochemical mechanisms that determine the fate of carbon inputs in soils. Geoderma 161, 182-193.

Wu, T., Ayres, E., Bardgett, R.D., Wall, D.H., Garey, J.R. 2011 Molecular study of worldwide distribution and diversity of soil animals. PNAS 108(43), 17720-17725.

Young, A. 1997. Agroforestry for Soil Management (No. Ed. 2). CAB international. 



\section{WORKING PAPERS WITH DOIS}

2005

1. Agroforestry in the drylands of eastern Africa: a call to action

2. Biodiversity conservation through agroforestry: managing tree species diversity within a network of community-based, nongovernmental, governmental and research organizations in western Kenya.

3. Invasion of prosopis juliflora and local livelihoods: Case study from the Lake Baringo area of Kenya

4. Leadership for change in farmers organizations: Training report: Ridar Hotel, Kampala, 29th March to 2nd April 2005.

5. Domestication des espèces agroforestières au Sahel : situation actuelle et perspectives

6. Relevé des données de biodiversité ligneuse: Manuel du projet biodiversité des parcs agroforestiers au Sahel

7. Improved land management in the Lake Victoria Basin: TransVic Project's draft report.

8. Livelihood capital, strategies and outcomes in the Taita hills of Kenya

9. Les espèces ligneuses et leurs usages: Les préférences des paysans dans le Cercle de Ségou, au Mali

10. La biodiversité des espèces ligneuses: Diversité arborée et unités de gestion du terroir dans le Cercle de Ségou, au Mali

2006

11. Bird diversity and land use on the slopes of Mt. Kilimanjaro and the adjacent plains, Tanzania

12. Water, women and local social organization in the Western Kenya Highlands

13. Highlights of ongoing research of the World Agroforestry Centre in Indonesia

14. Prospects of adoption of tree-based systems in a rural landscape and its likely impacts on carbon stocks and farmers' welfare: The FALLOW Model Application in Muara Sungkai, Lampung, Sumatra, in a 'Clean Development Mechanism' context

15. Equipping integrated natural resource managers for healthy Agroforestry landscapes.

17. Agro-biodiversity and CGIAR tree and forest science: approaches and examples from Sumatra.

18. Improving land management in eastern and southern Africa: A review of policies.

19. Farm and household economic study of Kecamatan Nanggung, Kabupaten Bogor, Indonesia: A socio-economic base line study of Agroforestry innovations and livelihood enhancement.

20. Lessons from eastern Africa's unsustainable charcoal business.

21. Evolution of RELMA's approaches to land management: Lessons from two decades of research and development in eastern and southern Africa

22. Participatory watershed management: Lessons from RELMA's work with farmers in eastern Africa.

23. Strengthening farmers' organizations: The experience of RELMA and ULAMP.

24. Promoting rainwater harvesting in eastern and southern Africa.

25. The role of livestock in integrated land management.

26. Status of carbon sequestration projects in Africa: Potential benefits and challenges to scaling up.

27. Social and Environmental Trade-Offs in Tree Species Selection: A Methodology for Identifying Niche Incompatibilities in Agroforestry [Appears as AHI Working Paper no. 9]

28. Managing tradeoffs in agroforestry: From conflict to collaboration in natural resource management. [Appears as AHI Working Paper no. 10]

29. Essai d'analyse de la prise en compte des systemes agroforestiers pa les legislations forestieres au Sahel: Cas du Burkina Faso, du Mali, du Niger et du Senegal.

30. Etat de la recherche agroforestière au Rwanda etude bibliographique, période 1987-2003

2007

31. Science and technological innovations for improving soil fertility and management in Africa: A report for NEPAD's Science and Technology Forum.

32. Compensation and rewards for environmental services.

33. Latin American regional workshop report compensation.

34. Asia regional workshop on compensation ecosystem services.

35. Report of African regional workshop on compensation ecosystem services. 
36. Exploring the inter-linkages among and between compensation and rewards for ecosystem services CRES and human well-being

37. Criteria and indicators for environmental service compensation and reward mechanisms: realistic, voluntary, conditional and pro-poor

38. The conditions for effective mechanisms of compensation and rewards for environmental services.

39. Organization and governance for fostering Pro-Poor Compensation for Environmental Services.

40. How important are different types of compensation and reward mechanisms shaping poverty and ecosystem services across Africa, Asia \& Latin America over the Next two decades?

41. Risk mitigation in contract farming: The case of poultry, cotton, woodfuel and cereals in East Africa.

42. The RELMA savings and credit experiences: Sowing the seed of sustainability

43. Yatich J., Policy and institutional context for NRM in Kenya: Challenges and opportunities for Landcare.

44. Nina-Nina Adoung Nasional di So! Field test of rapid land tenure assessment (RATA) in the Batang Toru Watershed, North Sumatera.

45. Is Hutan Tanaman Rakyat a new paradigm in community based tree planting in Indonesia?

46. Socio-Economic aspects of brackish water aquaculture (Tambak) production in Nanggroe Aceh Darrusalam.

47. Farmer livelihoods in the humid forest and moist savannah zones of Cameroon.

48. Domestication, genre et vulnérabilité : Participation des femmes, des Jeunes et des catégories les plus pauvres à la domestication des arbres agroforestiers au Cameroun.

49. Land tenure and management in the districts around Mt Elgon: An assessment presented to the Mt Elgon ecosystem conservation programme.

50. The production and marketing of leaf meal from fodder shrubs in Tanga, Tanzania: A pro-poor enterprise for improving livestock productivity.

51. Buyers Perspective on Environmental Services (ES) and Commoditization as an approach to liberate ES markets in the Philippines.

52. Towards Towards community-driven conservation in southwest China: Reconciling state and local perceptions.

53. Biofuels in China: An Analysis of the Opportunities and Challenges of Jatropha curcas in Southwest China.

54. Jatropha curcas biodiesel production in Kenya: Economics and potential value chain development for smallholder farmers

55. Livelihoods and Forest Resources in Aceh and Nias for a Sustainable Forest Resource Management and Economic Progress

56. Agroforestry on the interface of Orangutan Conservation and Sustainable Livelihoods in Batang Toru, North Sumatra.

57. Assessing Hydrological Situation of Kapuas Hulu Basin, Kapuas Hulu Regency, West Kalimantan.

58. Assessing the Hydrological Situation of Talau Watershed, Belu Regency, East Nusa Tenggara.

59. Kajian Kondisi Hidrologis DAS Talau, Kabupaten Belu, Nusa Tenggara Timur.

60. Kajian Kondisi Hidrologis DAS Kapuas Hulu, Kabupaten Kapuas Hulu, Kalimantan Barat.

61. Lessons learned from community capacity building activities to support agroforest as sustainable economic alternatives in Batang Toru orang utan habitat conservation program (Martini, Endri et al.)

62. Mainstreaming Climate Change in the Philippines.

63. A Conjoint Analysis of Farmer Preferences for Community Forestry Contracts in the Sumber Jaya Watershed, Indonesia.

64. The highlands: a shared water tower in a changing climate and changing Asia

65. Eco-Certification: Can It Deliver Conservation and Development in the Tropics.

66. Designing ecological and biodiversity sampling strategies. Towards mainstreaming climate change in grassland management.

67. Towards mainstreaming climate change in grassland management policies and practices on the Tibetan Plateau

68. An Assessment of the Potential for Carbon Finance in Rangelands

69 ECA Trade-offs Among Ecosystem Services in the Lake Victoria Basin.

69. The last remnants of mega biodiversity in West Java and Banten: an in-depth exploration of RaTA (Rapid Land Tenure Assessment) in Mount Halimun-Salak National Park Indonesia

70. Le business plan d'une petite entreprise rurale de production et de commercialisation des plants des arbres locaux. Cas de quatre pépinières rurales au Cameroun. 
71. Les unités de transformation des produits forestiers non ligneux alimentaires au Cameroun.

Diagnostic technique et stratégie de développement Honoré Tabuna et Ingratia Kayitavu.

72. Les exportateurs camerounais de safou (Dacryodes edulis) sur le marché sous régional et international. Profil, fonctionnement et stratégies de développement.

73. Impact of the Southeast Asian Network for Agroforestry Education (SEANAFE) on agroforestry education capacity.

74. Setting landscape conservation targets and promoting them through compatible land use in the Philippines.

75. Review of methods for researching multistrata systems.

76. Study on economical viability of Jatropha curcas L. plantations in Northern Tanzania assessing farmers' prospects via cost-benefit analysis

77. Cooperation in Agroforestry between Ministry of Forestry of Indonesia and International Center for Research in Agroforestry

78. "China's bioenergy future. an analysis through the Lens if Yunnan Province

79. Land tenure and agricultural productivity in Africa: A comparative analysis of the economics literature and recent policy strategies and reforms

80. Boundary organizations, objects and agents: linking knowledge with action in Agroforestry watersheds

81. Reducing emissions from deforestation and forest degradation (REDD) in Indonesia: options and challenges for fair and efficient payment distribution mechanisms

2009

82. Mainstreaming climate change into agricultural education: challenges and perspectives

83. Challenging conventional mindsets and disconnects in conservation: the emerging role of ecoagriculture in Kenya's landscape mosaics

84. Lesson learned RATA garut dan bengkunat: suatu upaya membedah kebijakan pelepasan kawasan hutan dan redistribusi tanah bekas kawasan hutan

85. The emergence of forest land redistribution in Indonesia

86. Commercial opportunities for fruit in Malawi

87. Status of fruit production processing and marketing in Malawi

88. Fraud in tree science

89. Trees on farm: analysis of global extent and geographical patterns of agroforestry

90. The springs of Nyando: water, social organization and livelihoods in Western Kenya

91. Building capacity toward region-wide curriculum and teaching materials development in agroforestry education in Southeast Asia

92. Overview of biomass energy technology in rural Yunnan (Chinese - English abstract)

93. A pro-growth pathway for reducing net GHG emissions in China

94. Analysis of local livelihoods from past to present in the central Kalimantan Ex-Mega Rice Project area

95. Constraints and options to enhancing production of high quality feeds in dairy production in Kenya, Uganda and Rwanda

2010

96. Agroforestry education in the Philippines: status report from the Southeast Asian Network for Agroforestry Education (SEANAFE)

97. Economic viability of Jatropha curcas L. plantations in Northern Tanzania- assessing farmers' prospects via cost-benefit analysis.

98. Hot spot of emission and confusion: land tenure insecurity, contested policies and competing claims in the central Kalimantan Ex-Mega Rice Project area

99. Agroforestry competences and human resources needs in the Philippines

100. CES/COS/CIS paradigms for compensation and rewards to enhance environmental Services

101. Case study approach to region-wide curriculum and teaching materials development in agroforestry education in Southeast Asia

102. Stewardship agreement to reduce emissions from deforestation and degradation (REDD): Lubuk Beringin's Hutan Desa as the first village forest in Indonesia

103. Landscape dynamics over time and space from ecological perspective

104. Komoditisasi atau koinvestasi jasa lingkungan: skema imbal jasa lingkungan program peduli sungai di DAS Way Besai, Lampung, Indonesia 
105. Improving smallholders' rubber quality in Lubuk Beringin, Bungo district, Jambi province, Indonesia: an initial analysis of the financial and social benefits

106. Rapid Carbon Stock Appraisal (RACSA) in Kalahan, Nueva Vizcaya, Philippines

107. Tree domestication by ICRAF and partners in the Peruvian Amazon: lessons learned and future prospects in the domain of the Amazon Initiative eco-regional program

108. Memorias del Taller Nacional: "Iniciativas para Reducir la Deforestación en la region Andino Amazónica", 09 de Abril del 2010. Proyecto REALU Peru

109. Percepciones sobre la Equidad y Eficiencia en la cadena de valor de REDD en Perú -Reporte de Talleres en Ucayali, San Martín y Loreto, 2009. Proyecto REALU-Perú.

110. Reducción de emisiones de todos los Usos del Suelo. Reporte del Proyecto REALU Perú Fase 1

111. Programa Alternativas a la Tumba-y-Quema (ASB) en el Perú. Informe Resumen y Síntesis de la Fase II. 2da. versión revisada

112. Estudio de las cadenas de abastecimiento de germoplasma forestal en la amazonía Boliviana

113. Biodiesel in the Amazon

114. Estudio de mercado de semillas forestales en la amazonía Colombiana

115. Estudio de las cadenas de abastecimiento de germoplasma forestal en Ecuador http://dx.doi.org10.5716/WP10340.PDF

116. How can systems thinking, social capital and social network analysis help programs achieve impact at scale?

117. Energy policies, forests and local communities in the Ucayali Region, Peruvian Amazon

118. NTFPs as a Source of Livelihood Diversification for Local Communities in the Batang Toru Orangutan Conservation Program

119. Studi Biodiversitas: Apakah agroforestry mampu mengkonservasi keanekaragaman hayati di DAS Konto?

120. Estimasi Karbon Tersimpan di Lahan-lahan Pertanian di DAS Konto, Jawa Timur

121. Implementasi Kaji Cepat Hidrologi (RHA) di Hulu DAS Brantas, Jawa Timur. http://dx.doi.org/10.5716/WP10338.PDF

122. Kaji Cepat Hidrologi di Daerah Aliran Sungai Krueng Peusangan, NAD,Sumatra http://dx.doi.org/10.5716/WP10337.PDF

123. A Study of Rapid Hydrological Appraisal in the Krueng Peusangan Watershed, NAD, Sumatra. http://dx.doi.org/10.5716/WP10339.PDF

\section{1}

124. An Assessment of farm timber value chains in Mt Kenya area, Kenya

125. A Comparative financial analysis of current land use systems and implications for the adoption of improved agroforestry in the East Usambaras, Tanzania

126. Agricultural monitoring and evaluation systems

127. Challenges and opportunities for collaborative landscape governance in the East Usambara Mountains, Tanzania

128. Transforming Knowledge to Enhance Integrated Natural Resource Management Research, Development and Advocacy in the Highlands of Eastern Africa http://dx.doi.org/10.5716/WP11084.PDF

129. Carbon-forestry projects in the Philippines: potential and challenges The Mt Kitanglad Range forestcarbon development http://dx.doi.org10.5716/WP11054.PDF

130. Carbon forestry projects in the Philippines: potential and challenges. The Arakan Forest Corridor forest-carbon project http://dx.doi.org10.5716/WP11055.PDF

131. Carbon-forestry projects in the Philippines: potential and challenges. The Laguna

Lake Development Authority's forest-carbon development project http://dx.doi.org/10.5716/WP11056.PDF

132. Carbon-forestry projects in the Philippines: potential and challenges. The Quirino forest-carbon development project in Sierra Madre Biodiversity Corridor http://dx.doi.org10.5716/WP11057.PDF

133. Carbon-forestry projects in the Philippines: potential and challenges. The Ikalahan Ancestral Domain forest-carbon development http://dx.doi.org10.5716/WP11058.PDF

134. The Importance of Local Traditional Institutions in the Management of Natural Resources in the Highlands of Eastern Africa http://dx.doi.org/10.5716/WP11085.PDF

135. Socio-economic assessment of irrigation pilot projects in Rwanda http://dx.doi.org/10.5716/WP11086.PDF

136. Performance of three rambutan varieties(Nephelium lappaceum L.) on various nursery media http://dx.doi.org/10.5716/WP11232.PDF 
137. Climate change adaptation and social protection in agroforestry systems: enhancing adaptive capacity and minimizing risk of drought in Zambia and Honduras http://dx.doi.org/10.5716/WP11269.PDF

138. Does value chain development contribute to rural poverty reduction? Evidence of asset building by smallholder coffee producers in Nicaragua http://dx.doi.org/10.5716/WP11271.PDF

139. Potential for biofuel feedstock in Kenya. http://dx.doi.org/10.5716/WP11272.PDF

140. Impact of fertilizer trees on maize production and food security in six districts of Malawi. http://dx.doi.org/10.5716/WP11281.PDF

\section{2}

141. Fortalecimiento de capacidades para la gestión del Santuario Nacional Pampa Hermosa:

Construyendo las bases para un manejo adaptativo para el desarrollo local. Memorias del Proyecto. http://dx.doi.org/10.5716/WP12005.PDF

142. Understanding rural institutional strengthening: A cross-level policy and institutional framework for sustainable development in Kenya http://dx.doi.org/10.5716/WP12012.PDF

143. Climate change vulnerability of agroforestry http://dx.doi.org/10.5716/WP16722.PDF

144. Rapid assesment of the inner Niger delta of Mali http://dx.doi.org/10.5716/WP12021.PDF

145. Designing an incentive program to reduce on-farm deforestationin the East Usambara Mountains, Tanzania http://dx.doi.org/10.5716/WP12048.PDF

146. Extent of adoption of conservation agriculture and agroforestry in Africa: the case of Tanzania, Kenya, Ghana, and Zambia http://dx.doi.org/10.5716/WP12049.PDF

147. Policy incentives for scaling up conservation agriculture with trees in Africa: the case of Tanzania, Kenya, Ghana and Zambia http://dx.doi.org/10.5716/WP12050.PDF

148. Commoditized or co-invested environmental services? Rewards for environmental services scheme: River Care program Way Besai watershed, Lampung, Indonesia. http://dx.doi.org/10.5716/WP12051.PDF

149. Assessment of the headwaters of the Blue Nile in Ethiopia. http://dx.doi.org/10.5716/WP12160.PDF

150. Assessment of the uThukela Watershed, Kwazaulu. http://dx.doi.org/10.5716/WP12161.PDF

151. Assessment of the Oum Zessar Watershed of Tunisia. http://dx.doi.org/10.5716/WP12162.PDF

152. Assessment of the Ruwenzori Mountains in Uganda. http://dx.doi.org/10.5716/WP12163.PDF

153. History of agroforestry research and development in Viet Nam. Analysis of research opportunities and gaps. http://dx.doi.org/10.5716/WP12052.PDF

154. REDD+ in Indonesia: a Historical Perspective. http://dx.doi.org/10.5716/WP12053.PDF

155. Agroforestry and Forestry in Sulawesi series: Livelihood strategies and land use system dynamics in South Sulawesi http://dx.doi.org/10.5716/WP12054.PDF

156. Agroforestry and Forestry in Sulawesi series: Livelihood strategies and land use system dynamics in Southeast Sulawesi. http://dx.doi.org/10.5716/WP12055.PDF

157. Agroforestry and Forestry in Sulawesi series: Profitability and land-use systems in South and Southeast Sulawesi. http://dx.doi.org/10.5716/WP12056.PDF

158. Agroforestry and Forestry in Sulawesi series: Gender, livelihoods and land in South and Southeast Sulawesi http://dx.doi.org/10.5716/WP12057.PDF

159. Agroforestry and Forestry in Sulawesi series: Agroforestry extension needs at the community level in AgFor project sites in South and Southeast Sulawesi, Indonesia. http://dx.doi.org/10.5716/WP12058.PDF

160. Agroforestry and Forestry in Sulawesi series: Rapid market appraisal of agricultural, plantation and forestry commodities in South and Southeast Sulawesi. http://dx.doi.org/10.5716/WP12059.PDF

2013

161. Diagnosis of farming systems in the Agroforestry for Livelihoods of Smallholder farmers in Northwestern Viet Nam project http://dx.doi.org/10.5716/WP13033.PDF

162. Ecosystem vulnerability to climate change: a literature review. http://dx.doi.org/10.5716/WP13034.PDF

163. Local capacity for implementing payments for environmental services schemes: lessons from the RUPES project in northeastern Viet Nam http://dx.doi.org/10.5716/WP13046.PDF

164. Seri Agroforestri dan Kehutanan di Sulawesi: Agroforestry dan Kehutanan di Sulawesi: Strategi mata pencaharian dan dinamika sistem penggunaan lahan di Sulawesi Selatan http://dx.doi.org/10.5716/WP13040.PDF

165. Seri Agroforestri dan Kehutanan di Sulawesi: Mata pencaharian dan dinamika sistem penggunaan lahan di Sulawesi Tenggara http://dx.doi.org/10.5716/WP13041.PDF

166. Seri Agroforestri dan Kehutanan di Sulawesi: Profitabilitas sistem penggunaan lahan di Sulawesi Selatan dan Sulawesi Tenggara http://dx.doi.org/10.5716/WP13042.PDF 
167. Seri Agroforestri dan Kehutanan di Sulawesi: Gender, mata pencarian dan lahan di Sulawesi Selatan dan Sulawesi Tenggara http://dx.doi.org/10.5716/WP13043.PDF

168. Seri Agroforestri dan Kehutanan di Sulawesi: Kebutuhan penyuluhan agroforestri pada tingkat masyarakat di lokasi proyek AgFor di Sulawesi Selatan dan Tenggara, Indonesia http://dx.doi.org/10.5716/WP13044.PDF

169. Seri Agroforestri dan Kehutanan di Sulawesi: Laporan hasil penilaian cepat untuk komoditas pertanian, perkebunan dan kehutanan di Sulawesi Selatan dan Tenggara http://dx.doi.org/10.5716/WP13045.PDF

170. Agroforestry, food and nutritional security http://dx.doi.org/10.5716/WP13054.PDF

171. Stakeholder Preferences over Rewards for Ecosystem Services: Implications for a REDD+ Benefit Distribution System in Viet Nam http://dx.doi.org/10.5716/WP13057.PDF

172. Payments for ecosystem services schemes: project-level insights on benefits for ecosystems and the rural poor http://dx.doi.org/10.5716/WP13001.PDF

173. Good practices for smallholder teak plantations: keys to success http://dx.doi.org/10.5716/WP13246.PDF

174. Market analysis of selected agroforestry products in the Vision for Change Project intervention Zone, Côte d'Ivoire http://dx.doi.org/10.5716/WP13249.PDF

175. Rattan futures in Katingan: why do smallholders abandon or keep their gardens in Indonesia's 'rattan district'? http://dx.doi.org/10.5716/WP13251.PDF

176. Management along a gradient: the case of Southeast Sulawesi's cacao production landscapes http://dx.doi.org/10.5716/WP13265.PDF

2014

177. Are trees buffering ecosystems and livelihoods in agricultural landscapes of the Lower Mekong Basin? Consequences for climate-change adaptation. http://dx.doi.org/10.5716/WP14047.PDF

178. Agroforestry, livestock, fodder production and climate change adaptation and mitigation in East Africa: issues and options. http://dx.doi.org/10.5716/WP14050.PDF

179. Trees on farms: an update and reanalysis of agroforestry's global extent and socio-ecological characteristics. http://dx.doi.org/10.5716/WP14064.PDF

180. Beyond reforestation: an assessment of Vietnam's REDD+ readiness. http://dx.doi.org/10.5716/WP14097.PDF

181. Farmer-to-farmer extension in Kenya: the perspectives of organizations using the approach. http://dx.doi.org/10.5716/WP14380.PDF

182. Farmer-to-farmer extension in Cameroon: a survey of extension organizations. http://dx.doi.org/10.5716/WP14383.PDF

183. Farmer-to-farmer extension approach in Malawi: a survey of organizations: a survey of organizations http://dx.doi.org/10.5716/WP14391.PDF

184. Seri Agroforestri dan Kehutanan di Sulawesi: Kuantifikasi jasa lingkungan air dan karbon pola agroforestri pada hutan rakyat di wilayah sungai Jeneberang

185. Options for Climate-Smart Agriculture at Kaptumo Site in Kenyahttp://dx.doi.org/10.5716/WP14394.PDF

2015

186. Agroforestry for Landscape Restoration and Livelihood Development in Central Asia http://dx.doi.org/10.5716/WP14143.PDF

187. "Projected Climate Change and Impact on Bioclimatic Conditions in the Central and South-Central Asia Region" http://dx.doi.org/10.5716/WP14144.PDF

188. Land Cover Changes, Forest Loss and Degradation in Kutai Barat, Indonesia http://dx.doi.org/10.5716/WP14145.PDF

189. The Farmer-to-Farmer Extension Approach in Malawi: A Survey of Lead Farmers. http://dx.doi.org/10.5716/WP14152.PDF

190. Evaluating indicators of land degradation and targeting agroforestry interventions in smallholder farming systems in Ethiopia. http://dx.doi.org/10.5716/WP14252.PDF

191. Land health surveillance for identifying land constraints and targeting land management options in smallholder farming systems in Western Cameroon

192. Land health surveillance in four agroecologies in Malawi

193. Cocoa Land Health Surveillance: an evidence-based approach to sustainable management of cocoa landscapes in the Nawa region, South-West Côte d'Ivoire http://dx.doi.org/10.5716/WP14255.PDF

194. Situational analysis report: Xishuangbanna autonomous Dai Prefecture, Yunnan Province, China. http://dx.doi.org/10.5716/WP14255.PDF 
195. Farmer-to-farmer extension: a survey of lead farmers in Cameroon. http://dx.doi.org/10.5716/WP15009.PDF

196. From transition fuel to viable energy source Improving sustainability in the sub-Saharan charcoal sector http://dx.doi.org/10.5716/WP15011.PDF

197. Mobilizing Hybrid Knowledge for More Effective Water Governance in the Asian Highlands http://dx.doi.org/10.5716/WP15012.PDF

198. Water Governance in the Asian Highlands http://dx.doi.org/10.5716/WP15013.PDF

199. Assessing the Effectiveness of the Volunteer Farmer Trainer Approach in Dissemination of Livestock Feed Technologies in Kenya vis-à-vis other Information Sources http://dx.doi.org/10.5716/WP15022.PDF

200. The rooted pedon in a dynamic multifunctional landscape: Soil science at the World Agroforestry Centre http://dx.doi.org/10.5716/WP15023.PDF 


The World Agroforestry Centre is an autonomous, non-profit research organization whose vision is a rural transformation in the developing world as smallholder households increase their use of trees in agricultural landscapes to improve food security, nutrition, income, health, shelter, social cohesion, energy resources and environmental sustainability. The Centre generates science-based knowledge about the diverse roles that trees play in agricultural landscapes, and uses its research to advance policies and practices, and their implementation that benefit the poor and the environment. It aims to ensure that all this is achieved by enhancing the quality of its science work, increasing operational efficiency, building and maintaining strong partnerships, accelerating the use and impact of its research, and promoting greater cohesion, interdependence and alignment within the organization.

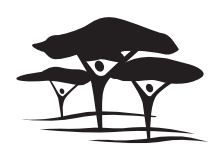

United Nations Avenue, Gigiri • PO Box 30677 • Nairobi, $00100 \cdot$ Kenya Telephone: +254 207224000 or via USA +1 6508336645 Fax: +254207224001 or via USA +1 6508336646 Email: worldagroforestry@cgiar.org•www.worldagroforestry.org

Southeast Asia Regional Program • Sindang Barang • Bogor 16680 PO Box $161 \cdot$ Bogor $16001 \cdot$ Indonesia

Telephone: +62 $2518625415 \cdot$ Fax: +62 2518625416 